\title{
Structure and biomass accumulation of natural mangrove forest at Gazi Bay, Kenya
}

\author{
MICHAEL NJOROGE GITHAIGA ${ }^{1, \vartheta}$, KIPLAGAT KOTUT ${ }^{2}$, FRANCIS KARIUKI $^{2}$, JAMES G. KAIRO ${ }^{1}$ \\ ${ }^{1}$ Marine Ecology and Environmental Programme, Kenya Marine and Fisheries Research Institute. Muthithi Rd, Nairobi, Kenya \\ vemail: githaiga.michael@embuni.ac.ke \\ ${ }^{2}$ Department of Plant and Microbial Sciences, Kenyatta University. P.O Box 43844-00100, Nairobi, Kenya
}

Manuscript received: 14 November 2019. Revision accepted: 8 January 2020.

\begin{abstract}
Githaiga MN, Kotut K, Kariuki F, Kairo JG. 2020. Structure and biomass accumulation of natural mangrove forest at Gazi Bay, Kenya. Bonorowo Wetlands 10: 18-32. This study aimed to determine the forest structure and estimate biomass accumulation above and below ground in the mangrove forest of Gazi Bay. The Gazi Bay mangrove forest's western, middle, and eastern forest blocks were investigated for forest structure, whereas the western forest block was determined for biomass accumulation. To calculate belowground biomass accumulation, in-growth cores of $80 \mathrm{~cm}$ long, $20 \mathrm{~cm}$ broad, and $60 \mathrm{~cm}$ deep were employed. Above-ground biomass accumulation was calculated using tree height and stem diameter data at breast height ( $\mathrm{DBH}-130)$. Tagging shoots observed leaf phenology. At the start, environmental variables were measured every four months for a year across four mangrove species zones. The linear regeneration sampling approach determined natural regeneration's composition and distribution pattern (LRS). Salinity revealed a strong negative connection with above-ground biomass accumulation among the soil environment characteristics studied. Sonneratia alba had the highest biomass accretion rate of $10.51 .9 \mathrm{t} \mathrm{ha-1} \mathrm{yr-1} \mathrm{among} \mathrm{the} \mathrm{four} \mathrm{forest} \mathrm{zones.} \mathrm{Rhizophora} \mathrm{mucronata}\left(8.50 .8 \mathrm{t} \mathrm{ha}^{-1} \mathrm{yr}^{-}\right.$ $\left.{ }^{1}\right)$, Avicennia marina $\left(5.21 .8 \mathrm{t} \mathrm{ha}^{-1} \mathrm{yr}^{-1}\right)$, and Ceriops tagal $\left(2.61 .5 \mathrm{t} \mathrm{ha}^{-1} \mathrm{yr}^{-1}\right)$ were the next most abundant species. Above-ground and below-ground biomass accumulation differed significantly among zones $\left(\mathrm{F}_{(3,8)}=5.42, p=0.025\right)$ and $\left(\mathrm{F}_{(3,8)}=16.03, p=0001\right)$, respectively. There was a significant difference in total biomass accumulation across zones $(\mathrm{F}(3,8)=15.56, p=0.001)$. A root: shoot biomass accumulation ratio of 2: 5 was calculated for the entire forest. This study's findings provide more accurate estimates of mangrove carbon capture and storage, which can be used in carbon credit discussions in the emerging carbon market.
\end{abstract}

Keywords: Biomass accumulation, Gazi Bay, Kenya, mangrove forest

\section{INTRODUCTION}

Mangroves are salt-tolerant plants and shrubs that grow along with the intertidal areas of tropical and subtropical coastlines. Millions of people in the tropics rely on keystone coastal ecosystems for economic, ecological, and environmental reasons. Mangroves provide essential habitats and feeding grounds for various benthic and pelagic marine animals and bird species and commercial fisheries resources and nursery grounds for coastal fisheries (Costanza et al. 1997; Saenger 2002; FAO 2007a; FAO 2007b) (). Among the tropics, up to $75 \%$ of commercial fish species spend part of their life cycle in mangroves (Mumby et al., 2008). Climate regulation, nutrient cycling, habitat provisioning, coastline protection, and the provision of building materials and fuelwood are all significant functions of mangroves. The global value of mangrove goods and services is estimated to be $\$ 1.6$ billion per year (FAO 2007b).

The world's mangroves cover 1.5 million square kilometers (Giri et al., 2011). This equates to around 0.4 percent of tropical forests or $\sim 12 \%$ of the total land area on the planet (Komiyama et al., 2002). Despite their modest size, they play an important part in the carbon cycle (Bouillon et al., 2008). Mangroves are one of the most prolific ecosystems on the planet, storing more than 1,000 $\mathrm{Mg} \mathrm{C} \mathrm{ha}{ }^{-1}$ on average. Carbon is stored in both living and dead wood, with sediment serving as the primary storage location (Donato et al., 2011).

Scientists are interested in understanding the potential function of mangroves in carbon capture and storage due to observed trends in global warming and the need for climate change mitigation. Reduced emissions from deforestation and degradation (or REDD+) are worldwide policies that focus on decreasing emissions and increasing carbon stocks by addressing deforestation, forest degradation, forest conservation, and sustainable forest management. Countries willing and able to reduce deforestation and forest degradation emissions will be reimbursed under the REDD+ program. Kenya has submitted a proposal to the World Bank's Forest Carbon Partnership Facility for REDD Readiness Preparation (R-RPP) (FCPF). This proposal lays out a plan for REDD preparatory operations, including how the work would be structured and managed and the financial resources required. Kenya intends to increase its forest cover to $10 \%$ with authorization, which will help mitigate climate change while also enhancing the livelihoods of forest-dependent populations through several advantages such as carbon credits.

The study's precise goals were to: (i) to analyze the forest structure across the three blocks of mangrove forest in Gazi Bay, (ii) to figure out how certain physicochemical parameters affect biomass accumulation in the Gazi mangrove forest, (iii) to determine the link between above- 
ground and below-ground biomass accumulation in each of the Gazi mangrove forest's species zones, (iv) to determine the variation in total biomass accumulation and AGB: BGB ratios of mangrove species in the Gazi mangrove forest's distinct zones.

\section{MATERIALS AND METHODS}

\section{Study site}

The study was carried out on the southern coast of Kenya, on a place called Gazi Bay $\left(4^{\circ} 25^{\prime} \mathrm{S}\right.$ and $\left.39^{\circ} 30^{\prime} \mathrm{E}\right)$, about $55 \mathrm{~km}$ away from Mombasa City (Figure 1).

The embayment has a surface area of $18 \mathrm{~km}^{2}$. The presence of the Chale peninsula to the east and a surrounding coral reef to the south protects it from severe waves. Gazi's mangrove area is estimated to be 615 hectares (Kairo et al. 2001). The Gazi Bay mangrove forest area is characterized by a sloping topography and a tidal amplitude of roughly $3.8 \mathrm{~m}$ with a maximum of $4.1 \mathrm{~m}$ (Kenya Ports Authority tide tables for Kilindini, Mombasa) (Matthijs et al. 1999). Two tidal creeks run through it. The western creek continues inland as the river Kidogoweni, while the eastern brook does not receive any freshwater. The Gazi mangrove forest was classified into three forest blocks based on the two streams, utilizing indices such as tree DBH, height, canopy cover, stand density quality of trees, and regeneration rates. The forest west of the Kidogoweni (western) creek at Gazi village is the western block, while the forest east of the Kinondo (eastern) creek near Kinondo village is the eastern block. Between the two creeks and near Makongeni village is the middle forest block. Soil physicochemical variables, biomass accumulation, and leaf phenology were analyzed on the western block.

\section{Study design}

A stratified random research design was utilized, with four zones representing the leading mangrove species in Gazi spread throughout the topographic gradient of the western forest block. Sonneratia alba represented the seaward zone, whereas Rhizophora mucronata, Ceriops tagal, and Avicennia marina represented the second, third, and upper zones, respectively. Two sites were chosen at distinct locations for $R$. mucronata and A. marina zones based on the growth and structural properties of the vegetation. In this study, A. marina in site " $\mathrm{A}$ " was in an area with dwarf mangroves near the landward side, but $A$. marina in site "B" was on the seaward side. In this study, $R$. mucronate in site "A" was at a lower tidal level, had a closed canopy, and had decreased regeneration, whereas $R$. mucronata in site "B" had an open canopy and high regeneration. The $C$. tagal stand consisted of stunted mature trees that stood no more than 2.0 meters tall and had a closed canopy. In each site, three plots of $10 \mathrm{~m}$ x $10 \mathrm{~m}$ were marked at a distance of $30 \mathrm{~m}$, for a total of 18 plots (Figure 2).
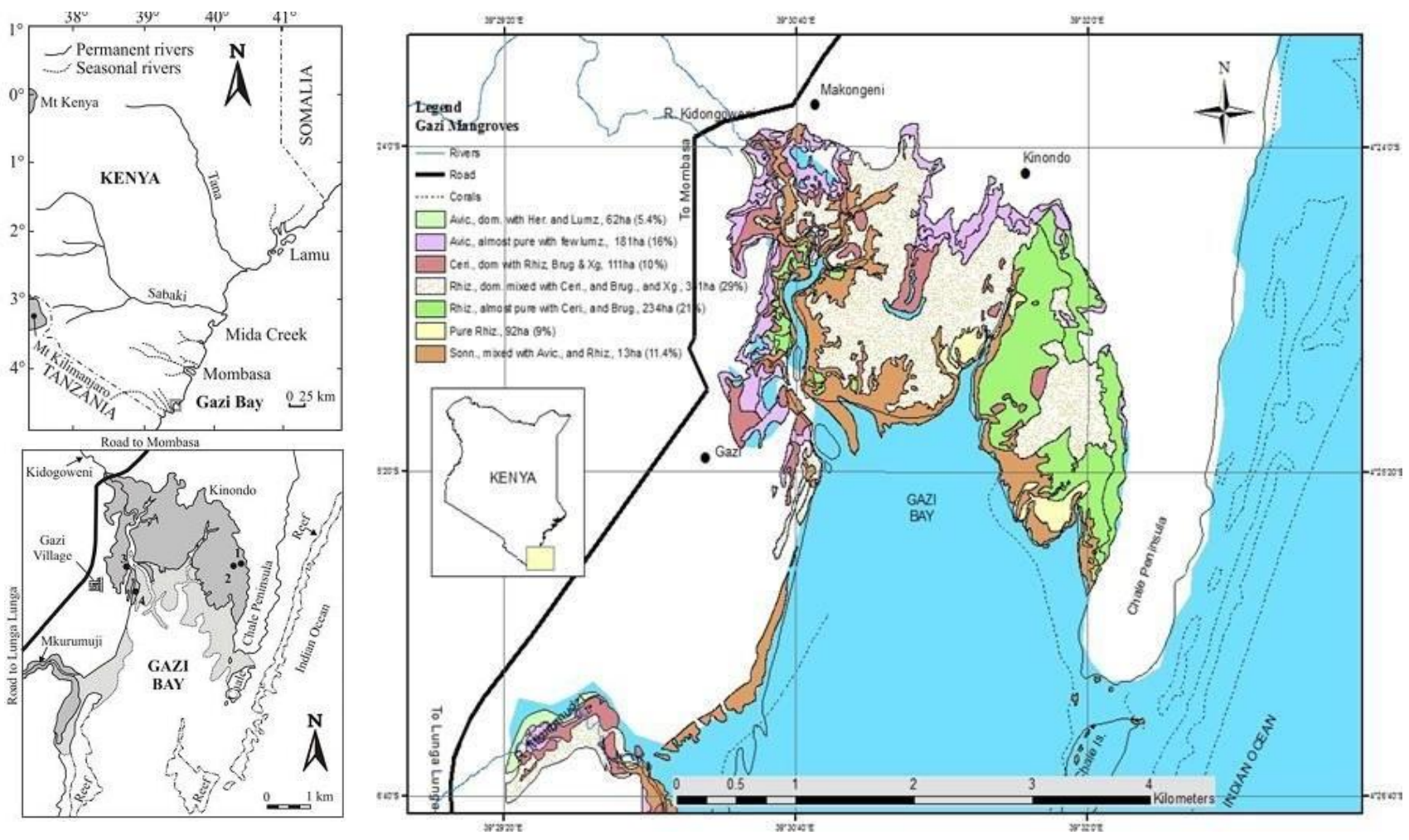

Figure 1. Map of the study site in the mangrove forest of Gazi Bay on the Kenyan Coast. (Source: Bosire et al. 2003) 


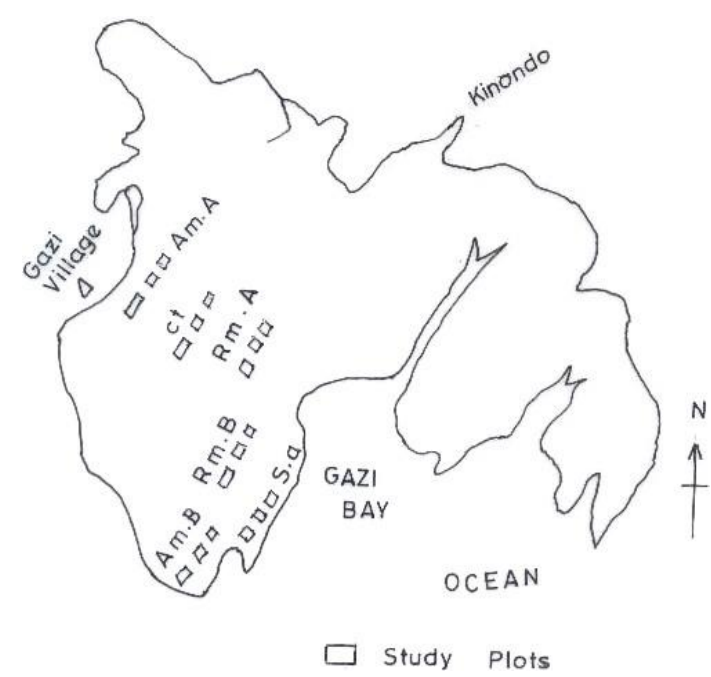

Figure 2. Plot layout for the present study at Gazi mangrove forest. (Am, Ct. Rm and Sa refer to Avicennia marina, Ceriops tagal, Rhizophora mucronate, and Sonneratia alba zones, respectively)

\section{Physicochemical factors}

\section{Measurement of height above datum}

The day's highest tidal level (Kilindini tides table 2011) was indicated as the benchmark or beginning reference point for subsequent observations to determine height above datum (HAD). The height above the datum of this point was calculated using the Kilindini tides table's daily estimate. A water-filled transparent hose pipe was placed on the ground, with one end of the pipe at the reference location.

The pipe was gently lifted to the next plot seawards until there was no water flow. The height from the ground was measured with a ruler held vertically to the watermark. The relative height of the plot was calculated by subtracting this height from the height of the reference point. This was done several times, passing through the plots towards the sea.

\section{Measurement of redox potential and $\mathrm{pH}$}

Sediment was collected monthly from four randomly chosen points inside the plot at depths of $10 \mathrm{~cm}$ and $40 \mathrm{~cm}$ to determine physicochemical soil properties. A multimeter was used to detect the sediment redox potential and $\mathrm{pH}$. (HANNA HI 8424 microcomputer $\mathrm{pH}$ meter).

\section{Sediment surface water salinity and temperature}

Sediment samples for salinity measurement were obtained from four random locations in the same plots, mixed, and transported in sample bags. The samples were centrifuged in the lab to extract the interstitial water. Salinity was measured using a hand-held refractometer (ATAGO, Tokyo, Japan). Temperatures of sediment surface water were measured in situ at four different locations throughout the plot.

\section{Sediment grain size analysis}

For granulometric analysis, surface scrapes of sediment samples weighing around 50 grams were obtained from four random points in each plot. The sediment samples were weighed and oven-dried at $80^{\circ} \mathrm{C}$ for 24 hours in the laboratory, after which they were reweighed to determine the percentage moisture content. For grain size analysis, approximately 25 grams of each sample's dry sediment was treated with $10 \mathrm{ml}$ of aqueous sodium hexametaphosphate and passed through a series of sieves with varied mesh apertures ranging from 63 to $500 \mathrm{~m}$ mesh size. The relative percentage of each particle in the sediment was calculated.

\section{Assessment of mangrove forest structure \\ Structural attributes of mangroves}

Mangrove trees with a Diameter at Breast Height $(\mathrm{DBH})$ of less than $5.0 \mathrm{~cm}$ were located and their locations documented. For A. marina and S. alba, the following parameters were measured: tree height $(\mathrm{m})$, crown cover $(\%)$, and stem diameter $(\mathrm{DBH})(\mathrm{cm})$ at $130 \mathrm{~cm}$ above the ground (D130). Due to the low height of the trees in $C$. tagal, stem diameter (DBH) was measured at $100 \mathrm{~cm}$ above ground, but stem diameter in $R$. mucronata trees was measured $30 \mathrm{~cm}$ above the highest prop root. The sum of the cross-sectional areas (CSA) of all trees in the species (m2 ha-1) at breast height was used to compute the basal area (BA) of each species. (See Equation (i) below) The sum of the number of stems per plot was divided by the area of the plot in $\mathrm{m} 2$ multiplied by 10,000 to get the stem density. (See Equation (ii) for further information.) By adding the relative density, relative frequency, and relative dominance of each species, the importance value index (IV) (a metric that shows the relative contribution of a plant species to the structure of a stand) was calculated (Cintron and Schaeffer-Novelli, 1984). (See Equation (iii) for further information).

The product of number of species, basal area (BA) $\left(\mathrm{m}^{2}\right.$ $\left.\mathrm{ha}^{-1}\right)$, maximum tree height $(\mathrm{m})$, and stem density $\left(\mathrm{D}, \mathrm{ha}^{-1}\right)$ $\mathrm{x} 10^{-5}$ was used to calculate the complexity index (Ic) of each forest zone (a measure of how complex or structurally developed a vegetation stand is) (Holdridge et al. 1971). The following are the equations: (i) $\mathrm{BA}\left(\mathrm{m}^{2} \mathrm{ha}^{-1}\right)=$ $\mathrm{CSA} /$ plot area $\left(\mathrm{m}^{2}\right) \times 10,000$. (ii) Stem density $\left(\right.$ Stems $\left.^{-1}\right)$ $=$ number of stems in plot/area of plot $\left(\mathrm{m}^{2}\right) \times 10,000$. (iii) Relative density + relative frequency + relative dominance. (iv) $I c=$ Number of species $\times \mathrm{BA}\left(\mathrm{m}^{2} \mathrm{ha}^{-1}\right) \mathrm{x}$ max. tree height $(\mathrm{m}) \times$ density $\left(\mathrm{ha}^{-1}\right) \times 10^{-5}$. The product of number of species, basal area (BA) $\left(\mathrm{m}^{2} \mathrm{ha}^{-1}\right)$, maximum tree height $(\mathrm{m})$, and stem density $\left(\mathrm{D}, \mathrm{ha}^{-1}\right) \times 10^{-5}$ was used to calculate the complexity index (Ic) of each forest zone (a measure of how complex or structurally developed a vegetation stand is) (Holdridge et al. 1971). The following are the equations: (i) BA $\left(\mathrm{m}^{2} \mathrm{ha}^{-1}\right)=\mathrm{CSA} /$ plot area $\left(\mathrm{m}^{2}\right) \times 10,000$. (ii) Stem density $\left(\right.$ Stems $\left.\mathrm{ha}^{-1}\right)=$ number of stems in plot/area of plot $\left(\mathrm{m}^{2}\right) \times 10,000$. (ii) $\mathrm{IV}=$ Relative density + relative frequency + relative dominance (iv) $I c=$ number of species $\mathrm{x}$ BA $\left(\mathrm{m}^{2} \mathrm{ha}^{-1}\right) \times$ max. tree height $(\mathrm{m}) \times$ density $\left(\mathrm{ha}^{-1}\right) \times 10^{-5}$.

\section{Quality of the mangrove poles}

Trees were classified into three form classes, 1, 2, and 3 , depending on the usefulness of the main stem in construction, to measure wood quality. Form 1 was assigned to trees with straight poles, whereas form 2 was 
assigned to trees with intermediate poles that required little adjustment before construction. Form class 3 was allocated to crooked poles that were inappropriate for construction.

\section{Natural regeneration}

The composition and pattern of natural regeneration were assessed using linear regeneration sampling (LRS) (Sukardjo 1987; FAO 1994; Kairo et al. 2002a). The occurrence of juveniles of various species was recorded and grouped according to their height classes and arbitrarily designated, Regeneration Classes (RC) I, II, or III, inside $5 \times 5 \mathrm{~m}^{2}$ subplots (within the main $(10 \times 10) \mathrm{m}^{2}$ quadrats). The ratio of RCI: II: III was used to evaluate the effectiveness of spontaneous regeneration (FAO 1994). Seedlings less than $40 \mathrm{~cm}$ height were designated as regeneration class 1 seedlings (RCI). RCII denoted saplings with a height of 40 to $150 \mathrm{~cm}$, whereas RCIII denoted small trees with a height of more than $1.5 \mathrm{~m}$ but a DBH of less than $2.5 \mathrm{~cm}$.

\section{Biomass accumulation estimates}

Above-ground biomass accumulation

Twelve trees were randomly selected for monitoring increment in stem diameter and height in each of the 18 plots measuring $10 \mathrm{~m} \times 10 \mathrm{~m}$. By measuring tree height (m) and stem diameter, above-ground biomass accumulation was estimated once every four months for a year. Cohen (2011) employed a general allometric equation derived for the Kenyan coast mangrove forests (In biomass =$2.29711+(\ln \mathrm{DBH} \times 2.54528)\left(\mathrm{R}^{2}=0.90\right)$ to determine above-ground biomass. Although various allometric formulas for the mangrove species in Gazi Bay exist, e.g., Slim et al. (1996), Kirui et al. (2006), Kairo et al. (2009), these were not utilized in this work to compute the aboveground biomass for several reasons. For starters, they were species-specific, and earlier equations were based on a small data set $(n=8-55$ trees vs. $n=337$ trees in Cohen (2011)). Furthermore, when evaluated, some of the equations were found to overestimate biomass at low $\mathrm{DBH}$; for example, Kirui et al. (2006) lowered biomass by a factor of 1.8 at low DBH but by a factor of 1.5 when $\mathrm{DBH}$ was increased.

\section{Below ground biomass increment}

The root in-growth core approach described by Vogt et al. was used to estimate below-ground biomass increment (1998). In the areas between the trees, two rectangular cores measuring $80 \mathrm{~cm}$ long by $20 \mathrm{~cm}$ wide and $60 \mathrm{~cm}$ deep were made in each of the 18 plots. The silt was removed from the cores, and the coarse roots (diameter > $3 \mathrm{~mm}$ ) were sorted out. The roots were macerated into minute bits to restore nutrients, mixed with the sediment, and returned to the core. Plastic pipes pegged at each corner of the cores were used to mark the positions of the cores. After a year, the cores were extracted, and new roots were divided into size classes of $3 \mathrm{~mm}, 3-5 \mathrm{~mm}, 5-10 \mathrm{~mm}$, 10-20 $\mathrm{mm}$, and $>20 \mathrm{~mm}$. To calculate the wet: dry weight ratio, the roots were weighed and oven-dried at $80^{\circ} \mathrm{C}$ to a constant dry weight, then reweighed.

\section{Total biomass and ratio of $B G B$ : $A B G$ : accumulation}

The sum of above-ground and below-ground biomass accumulation was used to compute total biomass accumulation. The BGB to AGB ratio was determined by dividing the below-ground biomass accumulation by the above-ground biomass accumulation.

\section{Leaf phenology}

Six twigs dispersed throughout the crown canopy of each of the 12 randomly selected trees per plot were tagged for phenological shot observations. The leaves on the chosen twig were numbered sequentially on the adaxial surface with a xylene-free permanent marker, with care made to avoid damaging the leaf epidermis. Any unnumbered leaves in the higher sections of the twig were classified as newly emerging in subsequent sampling. There was a loss of numbered leaves that was noted. The same twigs were examined monthly for a year's reproductive structures (buds, flowers, and fruits). Phenology research was crucial in determining when plants grew quickly, and seeds were ready for propagation.

\section{Data analysis}

Microsoft ® Excel spreadsheet 2007, MINITAB, or Statistical packages analyzed the data. All data were checked for normality and, if necessary, adjusted for parametric testing. Single classification ANOVA was used to examine the significance of mean values collected from two different Avicennia and Rhizophora sites. The data from the two sites were merged before being subjected to additional analysis because they were not statistically different for all of the cases studied. The mean biomass accumulation among the species was compared using ANOVA testing.

\section{RESULTS AND DISCUSSION}

\section{Soil physicochemical factors}

Height above datum of the four mangrove zones

Each of the four mangrove species has a different height above datum (HAD) than the others. S. alba was found on the seaward margin's lower tidal zone, with a mean HAD of $1.70 \pm 0.02$. The $R$. mucronata zone was adjacent with a mean HAD of $2.53 \pm 0.01 \mathrm{~m}$. $C$. tagal was found in the intermediate intertidal zone with a HAD of $2.86 \pm 0.01 \mathrm{~m}$, whereas A. marina was found on the landward margin with a HAD of $3.47 \pm 0.2 \mathrm{~m}$ (Means \pm 1 S.E.). Figure 3.

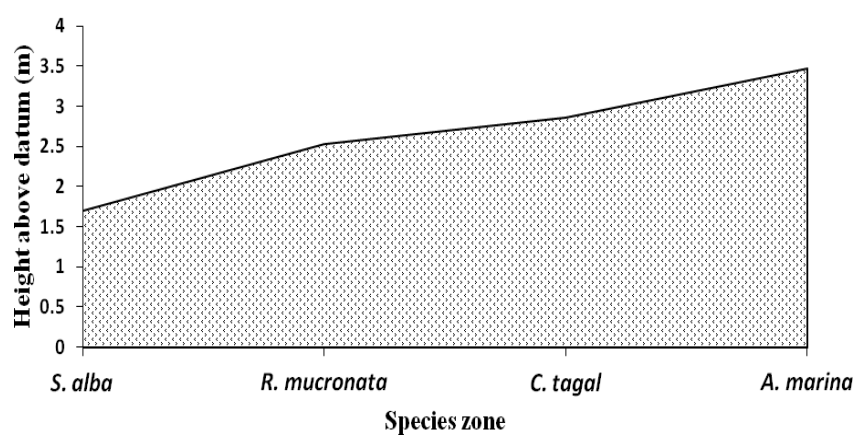

Figure 3. Species zone from the sea to the landward margin 


\section{Sediment physicochemical factors}

Salinity values in the $S$. alba species zone ranged from $32.0 \pm 0.2 \%$ during the dry season (January-April) to 30.0 $\pm 0.6 \%$ during the wet season (May-September). During the dry season, the redox potential was as high as $56.0 \pm 10$ $\mathrm{mV}$, while during the wet season, it was as low as-158.0 \pm $19 \mathrm{mV}$. During the dry season (January-April), $\mathrm{pH}$ ranged from 6.2 to 5.8, while during the rainy season (MaySeptember), $\mathrm{pH}$ ranged from 6.2 to 5.8. Temperatures ranged from $32.0 \pm 0.2{ }^{\circ} \mathrm{C}$ in the dry season (January to April) to $30.0 \pm 0.4{ }^{\circ} \mathrm{C}$ in the wet season (May to October) (May to September). Salinity values in the $R$. mucronata species zone ranged from $32.5 \pm 0.2 \%$ during the dry season (January-April) to $29.5 \pm 0.6 \%$ during the wet season (May-September). The redox potential was as high as-115.0 $26 \mathrm{mV}$ during the dry season, while during the rainy season, it was as low as-215.0 $\pm 9.3 \mathrm{mV}$. During both seasons, the $\mathrm{pH}$ range stayed consistent at 60 . Temperatures ranged from $30.0 \pm 0.4{ }^{\circ} \mathrm{C}$ in the dry season (January to April) to $39.9 \pm 0.2{ }^{\circ} \mathrm{C}$ in the wet season (May to October) (May to September).

In the $C$. tagal species zone, salinity levels ranged from $33.0 \pm 0.2 \%$ during the dry season (January-April) to 32.0 $\pm 0.2 \%$ during the wet season (May-September). During the dry season, redox potential ranged from-112.0 $\pm 58 \mathrm{mV}$ to- $197.0 \pm 62 \mathrm{mV}$, while during the rainy season, it ranged from-112.0 $\pm 58 \mathrm{mV}$ to-197.0 $\pm 62 \mathrm{mV}$. During the dry season (January-April), pH ranged from 6.1 to 5.2, while during the rainy season (May-October), $\mathrm{pH}$ ranged from 6.1 to 5.2. (May-September). Temperatures ranged from $38.0 \pm 0.2^{\circ} \mathrm{C}$ in the dry season (January to April) to $32.0 \pm$ $0.2{ }^{\circ} \mathrm{C}$ in the wet season (May to October) (May to September). Salinity levels in the A. marina species zone ranged from $48.0 \pm 0.5$ during the dry season (JanuaryApril) to $32.0 \pm 0.1$ during the wet season (MaySeptember). During the dry season, the redox potential was as high as-85.0 $\pm 6.0 \mathrm{mV}$, whereas it was as low as-112.0 \pm $58 \mathrm{mV}$ during the wet season. During the dry season (January-April), pH ranged from 6.1 to 4.7, while during the rainy season (May-September), $\mathrm{pH}$ ranged from 6.1 to 4.7. Temperatures ranged from $35.5 \pm 0.2^{\circ} \mathrm{C}$ in the dry season (January to April) to $32.0 \pm 0.2{ }^{\circ} \mathrm{C}$ in the wet season (May to October) (May to September). When environmental parameters were compared across the zones, it was discovered that substrate salinity levels ranged from $30 \%$ in the Sonneratia zone to $48 \%$ in the Avicennia zone. During the dry season, salinity was higher than during the wet season. During the dry season $\left(\mathrm{F}_{(3,8)}=13.13 ; p=\right.$ $0.002)$ and the rainy season $\left(\mathrm{F}_{(3,8)}=25.87 ; p=0.000\right)$, there was a substantial difference in salinity levels throughout the zones. Among the environmental factors studied, redox potential was the most variable. The Sonneratia zone had a high of $56.0 \mathrm{mV}$, while the Rhizophora zone had a low of-215.0 $\mathrm{mV}$. During the wet season, redox potential was significantly varied throughout the zones $\left(\mathrm{F}_{(3,8)}=27.38 ; p=0.000\right)$. During the dry season, however, the difference was not significant $\left(\mathrm{F}_{(3,8)}=5.70 ; p\right.$ $=0.0 .22$ ). The $\mathrm{pH}$ was slightly acidic in all zones, ranging from 4.7-6.5. During the dry season, $\mathrm{pH}$ values were significantly lower. In the four zones studied, the temperature of the substrate surface water ranged from a low of $30.0{ }^{\circ} \mathrm{C}$ to a high of $39.9{ }^{\circ} \mathrm{C}$. During the dry season, the temperature of the substrate did not differ substantially across the zones $\left(\mathrm{F}_{(3,8)}=1.87 ; p=0.214\right)$, but it did during the wet season $\left(\mathrm{F}_{(3,8)}=8.08 ; p=0.008\right)$.

\section{Sediment grain sizes}

Fine sand, coarse sand, and silt clay grain sizes accounted for $64.4 \%, 21 \%$, and $14.0 \%$ of sediments in the $S$. alba species zone, respectively (Figure 4). Fine sand, coarse sand, and silt clay accounted for $50 \%, 38.3 \%$, and $11.8 \%$ of the sediments in the Rhizophora species zone, respectively. The proportion of sediments belonging to distinct grain size classes in $C$. tagal species zones was $57.3 \%, 35 \%$, and $7.7 \%$ for silt clay, fine sand, and coarse sand, respectively. The percentage of sediments corresponding to different grain sizes in the A. marina species zone were $64 \%, 20.5 \%$, and $12.9 \%$ for fine sand, coarse sand, and silt clay, respectively.

\section{Mangrove forest structure \\ Importance value}

The primary mangrove species' importance values (IV) in the research site were determined as the sum of relative derivatives of frequency, dominance, and density ranging from 3.7 for $S$. alba to 191.3 for $R$. mucronata (Table 1). In the western, middle, and eastern forest blocks, $R$. mucronata had the highest IV values of 87.2, 146.9, and 191.3, respectively. C. tagal came in second, with importance values of $67.7,48.7$, and 23.3, respectively, for the western, middle, and eastern blocks. For the western, middle, and eastern forest blocks, A. marina rated importance values of $65.1,46.6$, and 21.5 , respectively. Bruguiera gymnorrhiza had importance values of 7.4, 46.6, and 52.4 in the western, middle, and eastern forest blocks, respectively, while Xylocarpus granatum had importance values of 59.2, 7.6, and 4.4 in the western, middle, and eastern forest blocks. For the western, middle, and eastern forest blocks, $S$. alba exhibited the lowest IV values of 13.0, 3.7, and 7.0, respectively (Table 1).

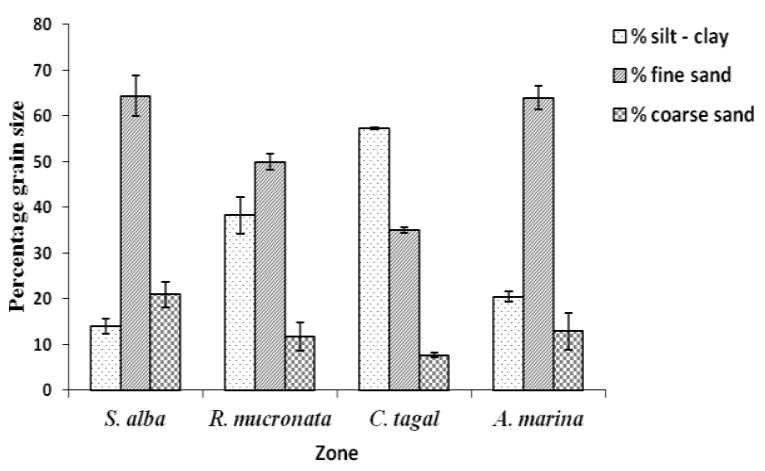

Figure 4. Percentage contribution of different grain sizes to the total sediment weight in different forest zones of Gazi mangrove forest 
Table 1. Structural attributes of the western, middle, and eastern forest blocks of Gazi mangroves, Kenya

\begin{tabular}{|c|c|c|c|c|c|c|c|}
\hline \multirow{2}{*}{$\begin{array}{l}\text { Forest } \\
\text { block }\end{array}$} & \multirow{2}{*}{ Species } & \multirow{2}{*}{$\begin{array}{c}\text { Stems } \\
\text { density ha-1 }\end{array}$} & \multirow{2}{*}{$\begin{array}{l}\text { Basal area } \\
\left(\mathbf{m}^{2} \mathbf{h a}^{-1}\right)\end{array}$} & \multicolumn{3}{|c|}{ Relative (\%) } & \multirow{2}{*}{ IV } \\
\hline & & & & Density & Dominance & Frequency & \\
\hline \multirow[t]{7}{*}{ Western (Gazi) } & A. marina & 323.0 & 3.43 & 24.69 & 25.04 & 15.38 & 65.1 \\
\hline & B. gymnorrhiza & 15.0 & 0.16 & 1.15 & 1.17 & 5.13 & 7.4 \\
\hline & C. tagal & 377.0 & 1.46 & 28.82 & 10.66 & 28.21 & 67.7 \\
\hline & R. mисronata & 308.0 & 4.50 & 23.55 & 32.85 & 30.77 & 87.2 \\
\hline & S. alba & 46.0 & 0.64 & 3.52 & 4.67 & 5.13 & 13.3 \\
\hline & $X$. granatum & 238.0 & 3.51 & 18.2 & 25.62 & 15.38 & 59.2 \\
\hline & Total & 1307 & 13.70 & 99.92 & 100 & 100 & 300 \\
\hline \multirow{7}{*}{$\begin{array}{l}\text { Middle } \\
\text { (Makongeni) }\end{array}$} & A. marina & 153.0 & 6.37 & 11.85 & 26.13 & 8.57 & 46.6 \\
\hline & B. gymnorrhiza & 133.0 & 3.97 & 10.3 & 16.28 & 20.0 & 46.6 \\
\hline & C. tagal & 243.0 & 1.72 & 18.82 & 7.05 & 22.86 & 48.7 \\
\hline & R. mucronata & 739.0 & 12.10 & 57.24 & 49.63 & 40 & 146.9 \\
\hline & S. alba & 6.0 & 0.09 & 0.46 & 0.37 & 2.86 & 3.7 \\
\hline & X. granatum & 18.0 & 0.13 & 1.39 & 0.53 & 5.71 & 7.6 \\
\hline & Total & 1292 & 24.38 & 100 & 100 & 100 & 300 \\
\hline \multirow{7}{*}{$\begin{array}{l}\text { Eastern } \\
\text { (Kinondo) }\end{array}$} & A. marina & 122.0 & 1.43 & 10.45 & 7.49 & 3.57 & 21.5 \\
\hline & B. gymnorrhiza & 156.0 & 3.36 & 13.37 & 17.63 & 21.43 & 52.4 \\
\hline & C. tagal & 72.0 & 0.55 & 6.17 & 2.88 & 14.29 & 23.3 \\
\hline & R. mucronata & 794.0 & 13.31 & 68.04 & 69.72 & 53.57 & 191.3 \\
\hline & S. alba & 17.0 & 0.37 & 1.46 & 1.94 & 3.57 & 7.0 \\
\hline & $X$. granatum & 6.0 & 0.06 & 0.51 & 0.31 & 3.57 & 4.4 \\
\hline & Total & 1167 & 19.89 & 100 & 100 & 100 & 300 \\
\hline
\end{tabular}

Table 2. Summary of structural characteristics of Gazi mangroves, Kenya

\begin{tabular}{|c|c|c|c|c|c|c|c|c|c|}
\hline Station & & Western & & & Middle & & & Eastern & \\
\hline Diameter class $(\mathrm{cm})$ & 5.1-10.0 & 10.1-15.0 & $>15.0$ & 5.1-10.0 & 10.1-15.0 & $>15.0$ & 5.1-10.0 & 10.1-15.0 & $>15.0$ \\
\hline No of species & 6 & 5 & 5 & 5 & 6 & 4 & 5 & 5 & 5 \\
\hline Stem density $\left(\mathrm{ha}^{-1}\right)$ & 1056 & 350 & 281 & 1520 & 1024 & 1024 & 1195 & 436 & 501 \\
\hline Mean height (m) & 3.70 & 5.20 & 6.90 & 4.80 & 5.68 & 6.90 & 5.33 & 13.40 & 23.0 \\
\hline Basal area $\left(\mathrm{m} \mathrm{ha}^{-1}\right)$ & 69.4 & 25.1 & 41.9 & 40.22 & 48.2 & 16.5 & 47.9 & 21.6 & 101.0 \\
\hline Complexity index* & 16.02 & 2.28 & 4.06 & 11.98 & 16.80 & 4.66 & 11.50 & 6.30 & 58.20 \\
\hline
\end{tabular}

Note: * The complexity index C.I. equals the product of (1), (2), (3), and (4) divided by $10^{5}$

\section{Complexity index}

The middle block was the most complex (10.81), while the western block was the least complicated (5.01), according to the structural complexity index (CI, which is derived as the product of the number of species, basal area, stand density, and mean height $\times 10^{-5}$ ). (Table 2). Tree height and diameter at breast height $(\mathrm{DBH})$ variation across the zones

There were significant variances in stem diameter and tree height within and across the different mangrove blocks studied. In the western block, $57 \%$ of the trees had a DBH between 5.1 and $9.0 \mathrm{~cm}, 20 \%$ had a DBH between 9.1 and $13.0 \mathrm{~cm}, 13 \%$ had a DBH between 13.1 and $17.0 \mathrm{~cm}, 6 \%$ had a DBH between 17.1 and $20.0 \mathrm{~cm}$, and $5 \%$ had a DBH more than $20.0 \mathrm{~cm}$. In the same block, $58 \%$ were between the height of 2.0 and 4.5 meters, $11 \%$ were between the height of 4.6 and 5.0 meters, and $30 \%$ were taller than 5 meters. In the middle block, $37 \%$ of the trees had a DBH between 5.1 and $9.0 \mathrm{~cm}, 25 \%$ had a DBH between 9.1 and $13.0 \mathrm{~cm}, 18 \%$ had a DBH between 13.1 and $17.0 \mathrm{~cm}, 8 \%$ had a DBH between 17.1 and $20.0 \mathrm{~cm}$, and $11 \%$ had a
DBH more than $20.0 \mathrm{~cm}$. In the same block, $35 \%$ had a height of 2.0-4.5 m, 25\% had a height of 4.6-5.0 m, and $40 \%$ had a height of $>5 \mathrm{~m}$. In the eastern block, $49 \%$ of the trees had a DBH of 5.1-9 $0 \mathrm{~cm}, 20 \%$ had a DBH of 91 $13.0 \mathrm{~cm}, 13 \%$ had a DBH of $13.1-170 \mathrm{~cm}, 5 \%$ had a DBH of $17.1-20.0 \mathrm{~cm}$, and $12 \%$ had a DBH more than $200 \mathrm{~cm}$. In the same block, $21 \%$ had a height of $2.0-4.5 \mathrm{~m}, 30 \%$ had a height of $4.6-5.0 \mathrm{~m}$, and $49 \%$ had a height of $>5 \mathrm{~m}$. (Figure 5). The connection between stem density and DBH size class distribution in all forest blocks showed a reverseJ curve (Figure 6).

\section{Stem density}

In the three forest blocks, mangrove densities were 1167,1292 , and 1307 stems ha $^{-1}$ in the eastern, middle, and western blocks, respectively, with a mean of $1255 \pm 44$ stems $\mathrm{ha}^{-1}$. The proportions of species present in the western block to its overall density were $29 \%$ (C. tagal), $25 \%$ (A. marina), 24\% (R. mucronata), 18\% (X. granatum), $4 \%$ (S. alba), and 1\% (B. gymnorrhiza). 

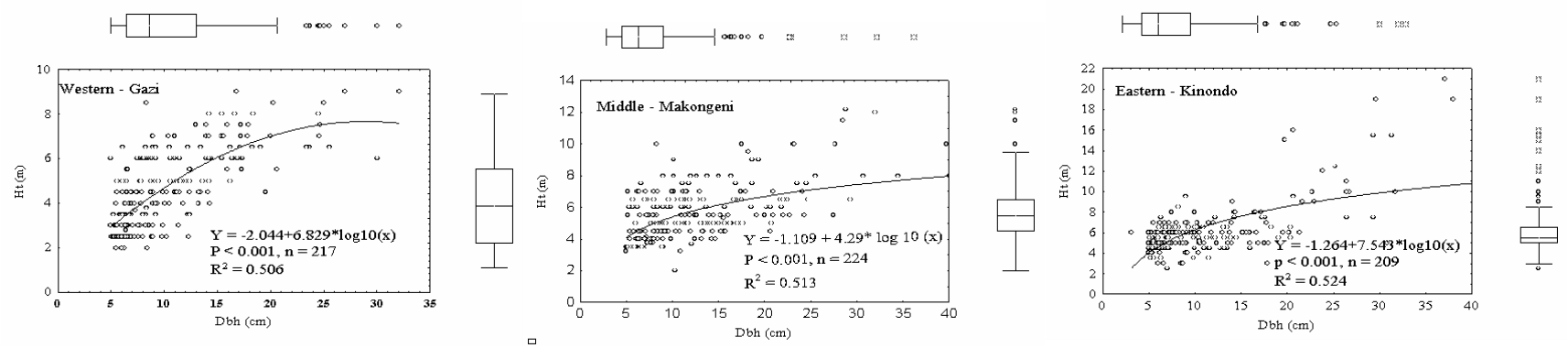

Figure 5. Height-diameter relationship in the three forest blocks of Gazi mangrove forest. The box plots display the percentile distribution of the DBH and heights in the forest blocks. The extremities of the plot correspond to the maximum and minimum observations in the data set. The ends of the boxes are positioned at the $25 \%$ and $75 \%$ percentile of the data.
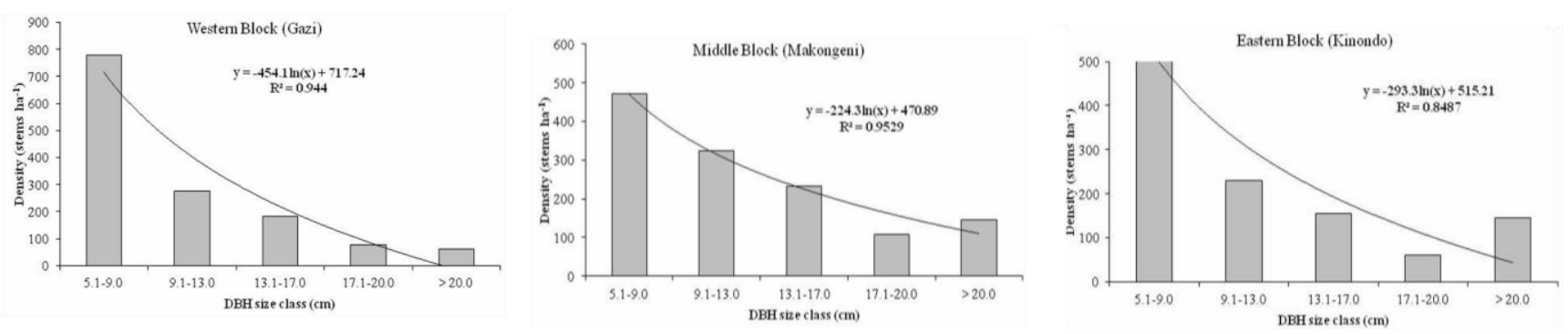

Figure 6. Stem density and DBH size class relations at Gazi Bay mangrove forest, Kenya

The relative contributions to total density in the middle block were $57 \%$ (R. mucronata), 19\% (C. tagal), $12.0 \%$ (A. marina), $10 \%$ (B. gymnorrhiza), 1.5\% (X. granatum) and $0.5 \%$. (S. alba). In the eastern block, contributions to total density were $68 \% \quad(R . \quad$ mucronata $), 13 \% \quad(B$. gymnorrhiza), $10 \%$ (A. marina),6\% (C. tagal), $1.5 \%$ ( $S$. alba) and $0.5 \%$ (X. granatum).

Quality classes of the stems in the mangrove forest

The western Gazi forest block had the lowest percentage of form class 1 poles $(2.4 \%)$, compared to $5.9 \%$ in the middle block and $10 \%$ in the eastern block, in terms of the quality of the poles. The western block had $34.1 \%$ in the form 2 size class category, compared to $53 \%$ and 54.9 $\%$ in the middle and eastern blocks, respectively. In contrast, the western block had $63.6 \%$ in the form 3 class category, compared to $41.2 \%$ and $35.2 \%$ in the middle and eastern blocks, respectively (Table 3 ).

\section{Natural regeneration}

Across all of Gazi's mangrove forest blocks, the density and composition of natural regeneration classes varied considerably (Table 4). In the western block, the regeneration class one $(\mathrm{RCI})$ density was 10,423 saplings $\mathrm{ha}^{-1}$, accounting for $48.4 \%$ of the overall juvenile density. The RCII were 3,579 seedlings per hectare, while the RCIII were 7,564 seedlings per hectare, representing $16.6 \%$ and $35 \%$, respectively (Table 4). RCI had a density of 47,618 seedlings $\mathrm{ha}^{-1}$ in the middle block, accounting for $59.6 \%$ of the total saplings. In comparison, established seedlings RCII and RCIII had densities of 13,614 and 18,608 seedlings $\mathrm{ha}^{-1}$, respectively, accounting for $17 \%$ and 23.3 $\%$ of the total seedlings.

Table 3. Quality classes of the poles in the three forest blocks of Gazi mangrove forest, Kenya

\begin{tabular}{llcccc}
\hline \multirow{2}{*}{ Forest block } & Species & \multicolumn{3}{c}{ Quality classes } & \multirow{2}{*}{ Total } \\
\cline { 2 - 4 } Western (Gazi) & A. marina & $\mathbf{1}$ & $\mathbf{2}$ & $\mathbf{3}$ & \\
& B. gymnorrhiza & 0 & 69 & 234 & 323 \\
& C. tagal & 8 & 177 & 192 & 16 \\
& R. mucronata & 15 & 115 & 177 & 307 \\
& S. alba & 8 & 23 & 15 & 46 \\
& X. granatum & 0 & 54 & 185 & 239 \\
& Total & 31 & 446 & 831 & 1307 \\
& Proportion $(\%)$ & 2.4 & 34.1 & 63.6 & \\
Middle & A. marina & 5 & 92 & 60 & 157 \\
(Makongeni) & B. gymnorrhiza & 11 & 65 & 54 & 130 \\
& C. tagal & 16 & 157 & 65 & 238 \\
& R. mucronata & 43 & 352 & 347 & 742 \\
& S. alba & 0 & 5 & 0 & 5 \\
& X. granatum & 0 & 11 & 5 & 16 \\
& Total & 76 & 683 & 531 & 1288 \\
& Proportion $(\%)$ & 5.9 & 53.0 & 41.2 & \\
Eastern & A. marina & 0 & 67 & 56 & 123 \\
(Kinondo) & B. gymnorrhiza & 33 & 39 & 83 & 155 \\
& C. tagal & 6 & 56 & 11 & 73 \\
& R. mucronata & 78 & 461 & 256 & 795 \\
& S. alba & 0 & 17 & 0 & 17 \\
& X. granatum & 0 & 0 & 6 & 6 \\
& Total & 177 & 640 & 412 & 1169 \\
& Proportion & 10.0 & 54.7 & 35.2 & \\
\hline
\end{tabular}


Table 4. Juvenile densities (saplings $\mathrm{ha}^{-1}$ ) in the three forest blocks of Gazi mangrove forest, Kenya

\begin{tabular}{llcccc}
\hline \multirow{2}{*}{ Site } & Species & \multicolumn{2}{c}{ Regeneration classes } & Total \\
\cline { 2 - 5 } Western (Gazi) & A. marina & 8 & 42 & 58 & 108 \\
& B. gymnorrhiza & 23 & 8 & 46 & 77 \\
& C. tagal & 5000 & 17 & 4008 & 9026 \\
& R. mucronata & 5385 & 3454 & 3377 & 12216 \\
& S. alba & 0 & 8 & 0 & 8 \\
& X. granatum & 17 & 50 & 75 & 142 \\
& Total & 10433 & 3579 & 7564 & 21576 \\
Middle & A. marina & 0 & 0 & 0 & 0 \\
(Makongeni) & B. gymnorrhiza & 783 & 94 & 117 & 994 \\
& C. tagal & 41169 & 6424 & 7191 & 54784 \\
& R. mucronata & 5666 & 7092 & 11300 & 24058 \\
& S. alba & 0 & 0 & 0 & 0 \\
& X. granatum & & 4 & 0 & 4 \\
Eastern & Total & 47618 & 13614 & 18608 & 79836 \\
(Kinondo) & A. marina & 22 & 0 & 6 & 28 \\
& B. gymnorrhiza & 144 & 161 & 1489 & 1794 \\
& C. tagal & 2872 & 1094 & 961 & 4927 \\
& R. mucronata & 12928 & 6883 & 5950 & 25761 \\
& S. alba & 0 & 0 & 0 & 0 \\
& X. granatum & 0 & 0 & 6 & 6 \\
& Total & 15966 & 8138 & 8412 & 32516 \\
\hline
\end{tabular}

RCI had a density of 15,966 saplings ha- 1 in the eastern block, accounting for $49.1 \%$ of the total saplings. In contrast, established saplings RCII and RCIII had densities of 8,138 and 8,412 saplings $\mathrm{ha}^{-1}$, accounting for $25 \%$ and $25.9 \%$ of the total saplings, respectively. The difference in mean sapling density in the three mangrove forest blocks was not significant $(\mathrm{F}(2,6)=1,163 ; \mathrm{p}=0.284)$, according to the one-way ANOVA test. The majority of the juveniles belonged to Rhizophora (56.9\%) and Ceriops (41\%), respectively, with the remaining saplings split between Bruguiera (1.9\%), Avicennia (0.1\%), and Xylocarpus $(0.1 \%)$. In the western, middle, and eastern forest blocks, the regeneration ratios for RCI, RCII, and RCIII were $3: 1: 2,3: 1: 1$, and $2: 1: 1$, respectively.

\section{Biomass accumulation estimates}

\section{Above-ground biomass accumulation}

In the study plots, above-ground biomass accumulation was highest in the Rhizophora zone, with a mean of $7.2 \pm 0.4 \mathrm{t} \mathrm{ha}^{-1} \mathrm{yr}^{-}$ ${ }^{1}$ (range: 6.3-7.8 t ha ${ }^{-1} \mathrm{yr}^{-1}$ ). The Sonneratia zone came next with a mean of $6.0 \pm 1.6 \mathrm{t} \mathrm{ha}^{-1} \mathrm{yr}^{-1}$ (range: 2.9-7.7 $\mathrm{t} \mathrm{ha}^{-1} \mathrm{yr}^{-1}$ ). The Avicennia zone had the third-highest mean biomass accumulation with $4.2 \pm 0.8 \mathrm{t} \mathrm{ha}^{-1} \mathrm{yr}^{-1}$ (range: 3.0-5.6 $\mathrm{t} \mathrm{ha}^{-1} \mathrm{yr}^{-1}$ ), while the Ceriops zone had the lowest mean biomass accumulation with 2.0 $\pm 0.7 \mathrm{t} \mathrm{ha}^{-1} \mathrm{yr}^{-1}$ (range: 0.8-3.4 $\mathrm{t} \mathrm{ha}^{-1} \mathrm{yr}^{-1}$ ) (Figure 7). The difference in mean above-ground biomass accumulation of the four species zones was determined to be significant $\left(\mathrm{F}_{(3,8)},=5.42\right.$; $p=0.025$ ) using a one-way ANOVA test.

\section{Below ground biomass accumulation}

The distribution of root weights into the four diameter size classes (less than $3 \mathrm{~mm}, 3-5 \mathrm{~mm}, 5-10 \mathrm{~mm}$, and more than $10 \mathrm{~mm}$ ) revealed that the lower size class category (less than $3 \mathrm{~mm}$ ) had higher root weights in all zones than the higher size class categories (Figure 8).

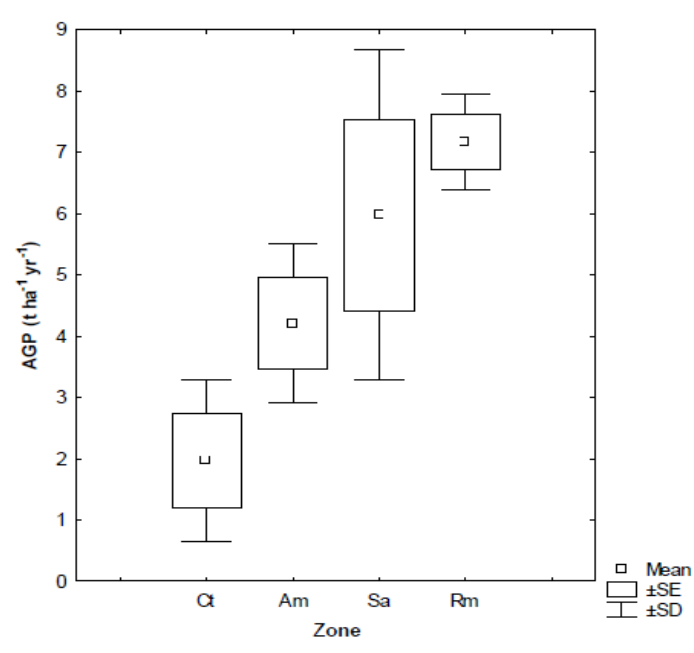

Figure 7. Above-ground biomass (AGB) accumulation rates at different vegetation zones of Gazi mangrove forest, Kenya. $(C \mathrm{t}$ : Ceriops, Am: Avicennia, Sa: Sonneratia and Rm: Rhizophora)

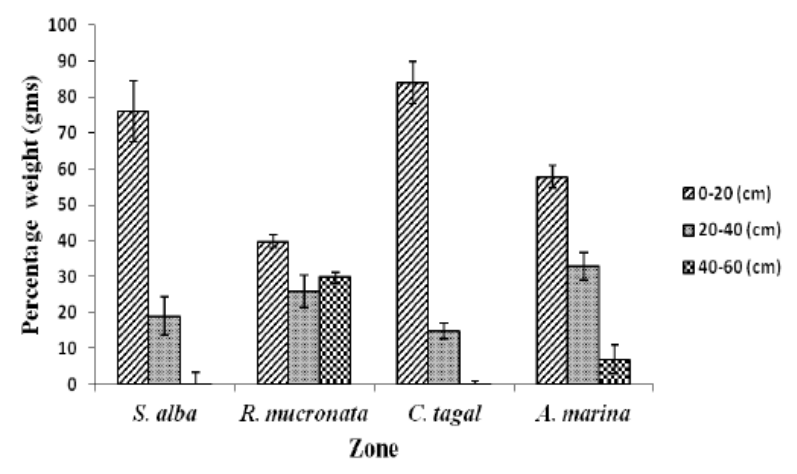

Figure 8. Percentage root weight distribution by depth in each zone at the Gazi mangrove forest

In the S. alba, R. mucronata, $C$. tagal, and A. marina zones, the smaller size class group of less than $3 \mathrm{~mm}$ produced root mean weights of $8,3,7$, and $3 \mathrm{~kg} \mathrm{ha}^{-1} \mathrm{yr}^{-1}$, respectively. S. alba, $R$. mucronata, $C$. tagal, and $A$. marina zones had mean root weights of $4,1,2$, and $3 \mathrm{~kg} \mathrm{ha}^{-}$ ${ }^{1} \mathrm{yr}^{-1}$, respectively, in the $3-5 \mathrm{~mm}$ size class. $S$. alba, $R$. mucronata, $C$. tagal, and A. marina zones had root weights of $15,1,5$, and $3 \mathrm{~kg} \mathrm{ha}^{-1} \mathrm{yr}^{-1}$, respectively, in the $5-10 \mathrm{~mm}$ size class. The root weights for the $S$. alba, R. mucronata, C. tagal, and A. marina zones were $18,1,4$, and $5 \mathrm{~kg} \mathrm{ha}^{-1}$ $\mathrm{yr}^{-1}$, respectively, in the larger size class category of more than $10 \mathrm{~mm}$.

The Sonneratia zone exhibited the largest biomass accumulation, with a mean of $4.5 \pm 0.9 \mathrm{t} \mathrm{ha}^{-1} \mathrm{yr}^{-1}$ (range: 3.9-5.5 $\mathrm{t} \mathrm{ha}^{-1} \mathrm{yr}^{-1}$ ) followed by the Avicennia zone with a mean of $1.7 \pm 0.6 \mathrm{t} \mathrm{ha}^{-1} \mathrm{yr}^{-1}$ (range: 1.3-2.5 $\mathrm{t} \mathrm{ha}^{-1} \mathrm{yr}^{-1}$ ). The Rhizophora zone had a mean below-ground biomass accumulation of $1.3 \pm 0.1 \mathrm{t} \mathrm{ha}^{-1} \mathrm{yr}^{-1}$ (range: 1.2-1.4 $\mathrm{t} \mathrm{ha}^{-1} \mathrm{yr}^{-}$ $\left.{ }^{1}\right)$ while the Ceriops zone had a mean of $0.6 \pm 0.4 \mathrm{t} \mathrm{ha}^{-1} \mathrm{yr}^{-1}$ (range: 0.3-1.0 $\mathrm{t} \mathrm{ha}^{-1} \mathrm{yr}^{-1}$ ) (Figure 9). The mean belowground biomass accumulation in the zones studied differed significantly $\left(\mathrm{F}_{(3,8)}=27.83 ; p=0.001\right)$, according to a one- 
way ANOVA test. Total biomass accumulation and the ratio of $A G B$ : $B G B$

The total biomass accumulation of each species was calculated by combining its above-and below-ground biomass accumulation. S. alba zone had the largest accumulation rate, averaging $10.5 \pm 1.9 \mathrm{t} \mathrm{ha}^{-1} \mathrm{yr}^{-1}$ (range: 8.4-11.9 $\mathrm{t} \mathrm{ha}^{-1}$ $\left.\mathrm{yr}^{-1}\right)$, followed by $R$. mucronata zone $\left(8.5 \pm 0.8 \mathrm{tha}^{-1} \mathrm{yr}^{-1}\right)$ (range 7.7-9.2 $\left.\mathrm{t} \mathrm{ha}^{-1} \mathrm{yr}^{-1}\right)$, A. marina zone $\left(5.2 \pm 1.8 \mathrm{t} \mathrm{ha}^{-1}\right.$ $\mathrm{yr}^{-1}$ ) (range: 3.3) (Figure 10). The overall biomass accumulation was significantly different among the mangrove zones, according to a one-way ANOVA test $\left(\mathrm{F}_{(3,}\right.$, 8) $=15.56 ; p=0.001)$. The ratio of below-ground $(\mathrm{BG})$ to above ground (AG) biomass accumulation (BG: $A G)$ in the $S$. alba zone was about $1: 1$, with below-ground biomass accumulation accounting for around $43 \%$ of total biomass accumulation. The BG: AG ratio in the A. marina zone was roughly $1: 2$, with below-ground biomass accumulation accounting for $33 \%$ of total biomass. The BG: AG ratio in the $C$. tagal zone was 1:3, with below-ground biomass accounting for $25 \%$ of total biomass. The lowest BG: AG ratio was found in the Rhizophora zone, which had a BG: AG ratio of 1:6 and accumulated $14 \%$ of the total biomass below ground. For the entire forest, a mean below ground to above-ground biomass accumulation ratio (BG: $\mathrm{AG}$ ) of 2:5 was calculated.

The distribution of root weights into the four diameter size classes (less than $3 \mathrm{~mm}, 3-5 \mathrm{~mm}, 5-10 \mathrm{~mm}$, and more than $10 \mathrm{~mm}$ ) revealed that the lower size class category (less than $3 \mathrm{~mm}$ ) had higher root weights in all zones than the higher size class categories. In the $S$. alba, $R$. mucronata, C. tagal, and A. marina zones, the smaller size class group of less than $3 \mathrm{~mm}$ produced root mean weights of $8,3,7$, and $3 \mathrm{~kg} \mathrm{ha}^{-1} \mathrm{yr}^{-1}$, respectively. $S$. alba, $R$. mucronata, $C$. tagal, and A. marina zones had mean root weights of 4, 1, 2, and $3 \mathrm{~kg} \mathrm{ha}^{-1} \mathrm{yr}^{-1}$, respectively, in the 3-5 mm size class. S. alba, R. mucronata, C. tagal, and A. marina zones had root weights of $15,1,5$, and $3 \mathrm{~kg} \mathrm{ha}^{-1} \mathrm{yr}^{-}$ ${ }^{1}$, respectively, in the $5-10 \mathrm{~mm}$ size class. The root weights

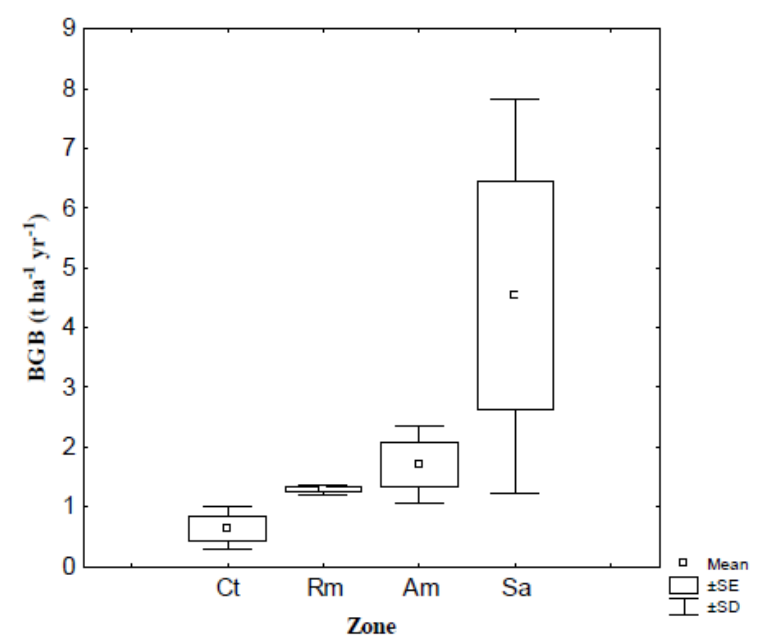

Figure 9. Below ground biomass accumulation at different vegetation zones of Gazi mangrove forest, Kenya. (Ct: Ceriops, Am: Avicennia, Sa: Sonneratia and Rm: Rhizophora) for the $S$. alba, R. mucronata, C. tagal, and A. marina zones were $18,1,4$, and $5 \mathrm{~kg} \mathrm{ha}^{-1} \mathrm{yr}^{-1}$, respectively, in the larger size class category of more than $10 \mathrm{~mm}$.

The Sonneratia zone exhibited the largest biomass accumulation, with a mean of $4.5 \pm 0.9 \mathrm{t} \mathrm{ha}^{-1} \mathrm{yr}^{-1}$ (range: 3.9-5.5 t ha $^{-1} \mathrm{yr}^{-1}$ ) followed by the Avicennia zone with a mean of $1.7 \pm 0.6 \mathrm{t} \mathrm{ha}^{-1} \mathrm{yr}^{-1}$ (range: $1.3-2.5 \mathrm{t} \mathrm{ha}^{-1} \mathrm{yr}^{-1}$ ). The Rhizophora zone had a mean below-ground biomass accumulation of $1.3 \pm 0.1 \mathrm{t} \mathrm{ha}^{-1} \mathrm{yr}^{-1}$ (range: 1.2-1.4 $\mathrm{t} \mathrm{ha}^{-1} \mathrm{yr}^{-}$ ${ }^{1}$ ) while the Ceriops zone had a mean of $0.6 \pm 0.4 \mathrm{t} \mathrm{ha}^{-1} \mathrm{yr}^{-1}$ (range: 0.3-1.0 $\mathrm{t} \mathrm{ha}^{-1} \mathrm{yr}^{-1}$ ) (Figure 9). The mean belowground biomass accumulation in the zones studied differed significantly $\left(\mathrm{F}_{(3,8)}=27.83 ; p=0.001\right)$, according to a oneway ANOVA test. Total biomass accumulation and the ratio of $\mathrm{AGB}$ : $\mathrm{BGB}$.

The total biomass accumulation of each species was calculated by combining its above-and below-ground biomass accumulation. S. alba zone had the largest accumulation rate, averaging $10.5 \pm 1.9 \mathrm{t} \mathrm{ha}^{-1} \mathrm{yr}^{-1}$ (range: 8.4-11.9 $\left.\mathrm{t} \mathrm{ha}^{-1} \mathrm{yr}^{-1}\right)$, followed by $R$. mucronata zone $(8.5 \pm$ $0.8 \mathrm{t} \mathrm{ha}^{-1} \mathrm{yr}^{-1}$ ) (range 7.7-9.2 $\mathrm{t} \mathrm{ha}^{-1} \mathrm{yr}^{-1}$ ), A. marina zone $\left(5.2 \pm 1.8 \mathrm{t} \mathrm{ha}^{-1} \mathrm{yr}^{-1}\right)$ (range: 3.3) (Figure 10). The overall biomass accumulation was significantly different among the mangrove zones, according to a one-way ANOVA test $\left(\mathrm{F}_{(3,8)}=15.56 ; p=0.001\right)$. The ratio of below-ground $(\mathrm{BG})$ to above ground (AG) biomass accumulation (BG: $A G)$ in the $S$. alba zone was about 1:1, with below-ground biomass accumulation accounting for around $43 \%$ of total biomass accumulation. The BG: AG ratio in the A. marina zone was roughly $1: 2$, with below-ground biomass accumulation accounting for $33 \%$ of total biomass. The BG: AG ratio in the $C$. tagal zone was 1:3, with below-ground biomass accounting for $25 \%$ of total biomass. The lowest BG: AG ratio was found in the Rhizophora zone, which had a BG: AG ratio of 1:6 and accumulated $14 \%$ of the total biomass below ground. For the entire forest, a mean below ground to above-ground biomass accumulation ratio (BG: $\mathrm{AG}$ ) of 2:5 was calculated.

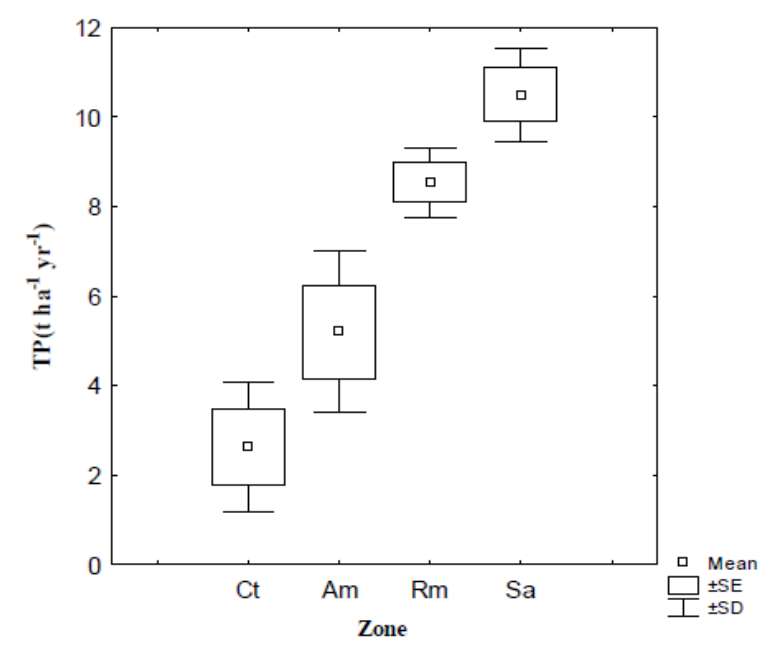

Figure 10. Total biomass accumulation at different vegetation zones at Gazi mangrove forest, Kenya. (Ct: Ceriops, Am: Avicennia, Sa:Sonneratia and Rm: Rhizophora) 


\section{Leaf phenology}

For the four studied species, leaf emergence ranged from two to four leaves per month (Figure 11). Sonneratia had the highest monthly leaf emergence count of $3.9 \pm 2$ leaves per twig, which peaked in October-November and gradually decreased during the observation period. The same species experienced a mean leaf loss of $3.2 \pm 2$ leaves per twig each month. As a result, in the $S$. alba zone, there was a net growth of 0.71 leaf per shoot per month. The average leaf emergence and loss in the $R$. mucronata zone were $2.8 \pm 2$ (range: one to five) and 1.41 (range: one to two), respectively, resulting in a net gain of $1.4 \pm 2$ leaves (range 1-3). Higher leaf emergence was seen at two peak times that coincided with the wet seasons (October to December and May to July), while low leaf emerging was seen during the dry season (March to May). Leaf emergence and loss per twig per month in the Avicennia zone ranged from one to seven (mean $2.3 \pm 2$ ) and one to two (mean $1.2 \pm 2$ ) leaves per twig per month, resulting in a mean net gain of $1.2 \pm 2$. During the dry months (December to February), leaf emergence was reduced, while leaf productivity peaked immediately after the arrival of rains at the end of April. Throughout the observation period, leaf loss was minimal and nearly consistent (Figure 11). Ceriops leaf emergence averaged $3.3 \pm 2$ leaves per twig per month, with a monthly loss of $1.1 \pm 1$ leaves per shoot resulting in a net gain of $2.2 \pm 2$ leaves per twig per month. Leaf emergence in $C$. tagal was bimodal, with peaks occurring between short rains (October-November) and long rains (December-January) (May-July). Between January and March, leaf productivity was low (Figure 11).

\section{Relationships}

According to the soil parameters studied, aboveground biomass accumulation was adversely linked with the mean salinity of the soil throughout both the dry and wet seasons. The relationship between temperature and above-ground biomass accumulation, on the other hand, was only significant during the wet season (Table 5). The following regression equations can be used to express the functional relationship between above ground and below-ground biomass accumulation for each zone:

S. alba zone: $\mathrm{BGB}=0.592 \ln (\mathrm{AGB})+2.351, \mathrm{r}^{2}=0.026$

R. mucronata zone: $\mathrm{BGB}=-1.49 \mathrm{In}(\mathrm{AGB})+3.1622, \mathrm{r}^{2}=0.112$

C. tagal zone: $\mathrm{BGB}=0.239 \mathrm{In}(\mathrm{AGB})+0.6935, \mathrm{r}^{2}=0.092$

A. marina zone: $\mathrm{BGB}=0.493 \mathrm{In}(\mathrm{AGB})+1.555, \mathrm{r}^{2}=0.66$
All of the other species zones had low $\mathrm{r} 2$ values, except the Avicennia species zone; thus, this equation for the Avicennia species zone is useful in estimating the belowground biomass accumulation from the above-ground biomass accumulation, whereas those for $S$. alba, $R$. mucronata, and C. tagal species zone are of limited value.

\section{Discussion}

\section{Mangrove forest structure}

Importance value (IV) of mangrove species

The leading species in the Gazi Bay mangrove forest was $R$. mucronata, followed by $C$. tagal, A. marina, B. gymnorrhiza, X. granatum, and $S$. alba, according to the structural composition of species defined by the importance value. Other mangrove forests in Kenya, such as Kiunga, Kairo et al. (2002b), and Vanga on the south coast, have a similar structural composition (Kairo et al. 2012). Macnae (1968) found it in different West Indian Ocean (WIO) mangrove formations, as well as in the mangroves of Puttalam Lagoon and Dutch Bay in Sri Lanka (Amarasinghe and Balasubramaniam 1992).

Height above datum contributed to species zonation at Gazi Bay mangrove forest, as evidenced by a considerable variance in height above datum for the four zones. Due to its inability to endure large salinity fluctuations, S. alba occupied the seaward side in inundation class I of Watson (1928). The Sonneratia trees could survive the floods due to their well-developed pneumatophores. The $R$. mucronata zone, which is inundation class II, is located next to the $S$. alba zone. Rhizophora trees' well-developed prop roots allow them to survive strong tide velocities and trap sediments. The C. tagal zone is found in the mid-tide zone, classified as inundation class III. Ceriops is one of the most challenging mangrove tree species, with an extensive salinity tolerance range. Ceriops grow to a shrub in high saline environments, such as those found in Gazi, but in fewer saline environments, such as those found in Mida Creek, the species can reach a height of more than 25 meters (Kairo et al. 2012). A. marina, found on the landward edge, falls under inundation class IV. A. marina, like Ceriops, can survive a wide range of salinity, which it controls using a secretion mechanism (Schmitz et al., 2007). Double zonation was seen in Avicennia in Gazi (Wang'ondu et al., 2010). Avicennia grows as huge trees with high $\mathrm{DBH}$ in low salinity areas on the seaward side but as scrub with low production in greater salinity areas on the landward side.

Table 5. Pearson correlation coefficient between above-ground biomass (AGB) accumulation and selected soil environment properties during the dry season (DS) and the rainy season (WS) at Gazi mangrove forest.

\begin{tabular}{|c|c|c|c|c|c|c|c|c|c|c|}
\hline \multirow{2}{*}{ Zone } & \multicolumn{2}{|c|}{ Salinity } & \multicolumn{2}{|c|}{ Redox } & \multicolumn{3}{|c|}{ Temperature } & \multicolumn{2}{|c|}{ pH } & \multirow[t]{2}{*}{$\mathbf{n}$} \\
\hline & & DS & WS & DS & WS & DS & WS & DS & WS & \\
\hline \multirow[t]{2}{*}{ S. alba } & $r=$ & -0.990 & -0.999 & 0.663 & 0.707 & 0.431 & 0.287 & 0.006 & 0.428 & 3 \\
\hline & $p=$ & 0.023 & 0.029 & 0.539 & 0.501 & 0.716 & 0.640 & 0.950 & 0.546 & \\
\hline \multirow[t]{2}{*}{ R. mucronata } & $r=$ & -0.852 & -0.932 & 0.854 & 0.813 & -0.859 & 0.135 & 0.316 & 0.905 & 6 \\
\hline & $p=$ & 0.031 & 0.007 & 0.031 & 0.049 & 0.028 & 0.799 & 0.620 & 0.013 & \\
\hline \multirow[t]{2}{*}{ C. tagal } & $r=$ & -0.328 & -0.960 & 0.143 & 0.306 & 0.135 & 0.303 & 0.376 & 0.370 & 3 \\
\hline & $p=$ & 0.787 & 0.029 & 0.629 & 0.627 & 0.799 & 0.804 & 0.580 & 0.759 & \\
\hline \multirow[t]{2}{*}{ A. marina } & $\mathrm{r}=$ & -0.970 & -0.973 & 0.354 & 0.309 & -0.409 & 0.019 & -0.398 & 0.287 & 6 \\
\hline & $p=$ & 0.001 & 0.001 & 0.491 & 0.551 & 0.420 & 0.912 & 0.434 & 0.581 & \\
\hline
\end{tabular}



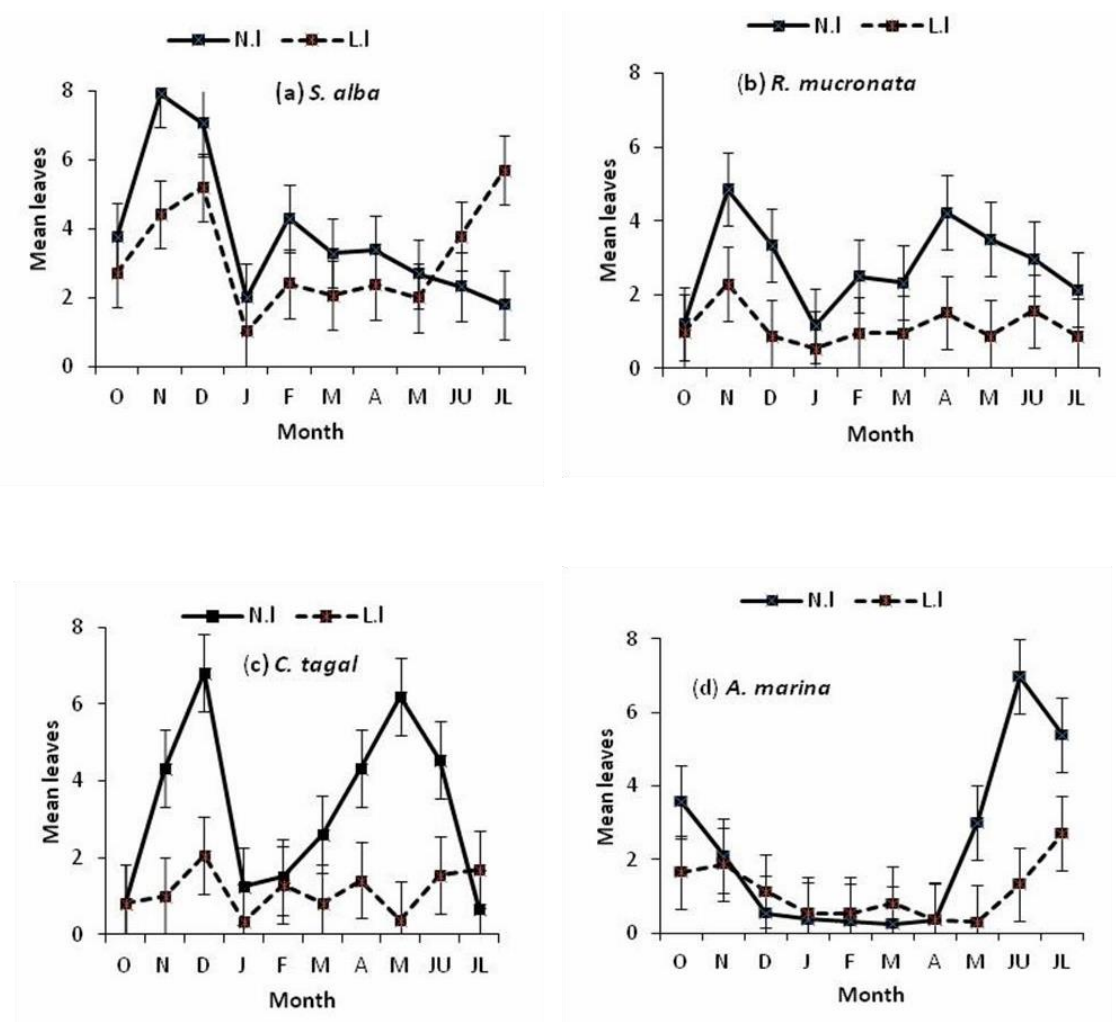

Figure 11. Mean leaf emergence and loss at different zones of the Gazi mangrove forest $($ Means \pm 1 S.E $)$. N.l = new leaves, L.l = lost leaves)

\section{Complexity index}

The high complexity index of the middle forest block suggested that the trees had a larger basal area and canopy height than the western and eastern blocks (Table 2), which could be due to less harvesting. The middle and eastern forest blocks at Gazi were substantially more complex than the western forest block. This is to be expected, given that the western forest block borders the human settlement of Gazi village and that previous removal of wood products has lowered the quality of mangroves in the area (Kairo 2001). According to the current study, $63.5 \%$ of trees in the western block were of quality class 3 , whereas tree quality in the middle and eastern blocks was primarily of class 1 and 2 (Table 3). Human impacts on the wood quality decline were generally greater in Gazi than in Mida Creek, where a considerable percentage of the poles were of quality class 1 . In contrast to the former, Mida Creek is a conservation area where tree removal is strictly controlled (Kairo et al. 2002a).

\section{Tree height and DBH relationship across zones}

The proximity to human settlements can be linked to differences in stem diameter and height observed in the three analyzed blocks. The western forest block has the highest percentage $(57 \%)$ of low-size class trees (Table 3). The western block was the most accessible and close to Gazi village. As a result, this forest block is subjected to more extraction pressure than the others.

\section{Stem density}

In the Gazi mangrove forest, the average stem density was $1255 \pm 44$, which is comparable to other mangrove habitats in Kenya. Mohamed et al. (2009) found a density

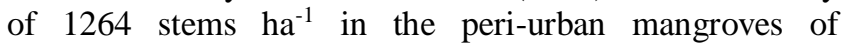

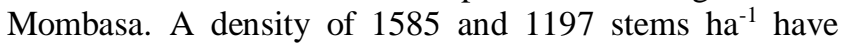
been recorded in Uyombo and Kirepwe of Mida Creek, respectively (Kairo et al. 2002a). Kairo et al. (2002a) found a density of 2077 stems ha $^{-1}$ in the Kiunga mangroves and 1934 trees ha-1 in the Vanga mangroves (Kairo et al. 2012). As a result, the stem density of natural mangrove stands was lower than that of the replanted mangrove forest of Gazi, which had a density of about 2500 stems ha-1 (Kairo 2001). This was attributed to the natural stands' poles being harvested regularly instead of the replanted stands, which were not. The observed "J" distribution curves (Figure 6) are characteristic of natural mangrove forests and show that poles were cut selectively. Mangrove forests in Kenya have been poorly maintained, as seen by low stem density in natural forest stands. As a result, a management plan for mangrove forests, similar to other upland forests, is required to ensure the supply of needed goods and services.

\section{Natural regeneration}

The recruitment of juveniles in the western forest block (21,576 juveniles), middle forest block (79,836 juveniles), and eastern forest block (32,516 juveniles) may be deemed appropriate, as FAO (1994) defines adequate regeneration density as more than 2500 saplings ha ${ }^{-1}$. Bosire et al. (2008) found a 50-61\% mortality rate by the end of year two in a two-year study of sapling survival and structural development in natural and reforested mangroves of Gazi. The survival rate ranged from 1230 to 5277 seedlings ha ${ }^{-1}$ in the same study. When the results of this study are compared to previous data, it appears that this forest can 
recover. On the other hand, reforestation modifies local hydrodynamics and other physical-chemical variables, resulting in higher regeneration in reforested areas (Bosire et al., 2003).

In the $S$. alba zone, there was very little understory. A combination of limited propagule influx, washing by wave activity, and shading impacts could have resulted in seedling recruitment failure in the $S$. alba zone. Seedling growth and survival in mangrove habitats are hampered by less light beneath closed canopies (Clarke and Kerrigan 2002). Natural mangrove regeneration is aided by canopy gaps (Sherman et al. 2000). Reduced resource competition (notably greater light availability) and crab predation are the reasons. Gradual sediment movement seen in the $S$. alba zone may be altering substrate conditions, making seedling establishment unfavorable.

\section{Quality of the stems in the mangrove forest of Gazi}

Most of the good quality poles (class 1) in the Gazi mangrove forest have been cut, leaving only $2.4 \%, 5.9 \%$, and $10 \%$ in the western, middle, and eastern blocks, respectively. The forest, on the other hand, has a higher percentage of class 2 and 3 in the forest blocks (class 2: $34.1 \%, 52.9 \%$, and $54.8 \%$; class 3: $63.5 \%, 41.2 \%$, and $35.2 \%$ at the western, middle and eastern blocks respectively). Higher percentages of class 2 and 3 poles indicate degraded forest, and the Gazi mangrove forest can thus be classified as degraded. The western forest block appears to be more deteriorated than the other two forest blocks based on relative percentages for the three-class groups. Trees with crooked poles of low commercial value were left out after straight poles were cut down in the Gazi mangrove forest (Kairo et al. 2010). This has long-term consequences because this forest may no longer be capable of providing building poles, a valuable ecosystem function to coastal populations. At the same time, biomass stocks will be depleted. Disparities in human pressure can be blamed for the differences in forest quality between the three locations. The proximity of human settlements to the mangroves of the western block and the fact that people from across the creek come here to cut trees leads to increased consumptive wood extraction from the forest, resulting in fewer mangrove poles. Mangrove poles in Kenya are classified and sold according to their diameter classes, which include Fito/Pau $(6.0 \mathrm{~cm})$, Mazio (8.0-11.0 $\mathrm{cm})$, Boriti (11.5-13.5 cm), and Banaa (20.1-35 cm). More stems in the bigger diameter classes, taller vegetation, and a higher total tree density have resulted from less exploitation in the middle block.

\section{Biomass accumulation estimates}

Above-ground biomass accumulation

According to this study, the accumulation of aboveground biomass in the four mangrove species zones differed significantly. This could be due to various reasons, including age, structural characteristics of the species, substrate conditions, and management strategies. The structural elements of the $R$. mucronata zone account for the substantial above-ground biomass accumulation. Rhizophora, unlike other species, has prop roots that can be regarded as part of the above-ground biomass. Because $R$. mucronata produces better poles, the older trees have been cut in the past, leaving younger trees to thrive quicker. The ancient age of the trees and the saline substrate stresses the trees, resulting in low aboveground biomass accumulation in C. tagal. Above-ground biomass accumulation in natural mangrove stands has ranged from a low of $2.02 \mathrm{t} \mathrm{ha}^{-1} \mathrm{yr}^{-1}$ in Avicennia germinas, a dominated stand in Mexico (Day et al. 1996), to a high of $26.7 \mathrm{t} \mathrm{ha}^{-1} \mathrm{yr}^{-1}$ in Rhizophora apiculata in southern Thailand (Christensen 1978). In Kenya, a 12-year replanted of $R$. mucronata increased above-ground biomass of $8.89 \mathrm{t} \mathrm{ha}^{-1} \mathrm{yr}^{-1}$ (Kairo et al. 2008). Changes in aboveground biomass accumulation could be caused by differences in environmental circumstances or plant traits.

\section{Below ground biomass accumulation}

Sonneratia alba zone had a high biomass accumulation of $4.50 .9 \mathrm{t} \mathrm{ha}^{-1} \mathrm{yr}^{-1}$, while Ceriops had biomass of $0.60 .4 \mathrm{t}$ $\mathrm{ha}^{-1} \mathrm{yr}^{-1}$. The differences in BGB accumulation within the zones could be ascribed to both species-specific features and site factors. Sonneratia grows faster than $C$. tagal in general. Kairo et al. (2002a) found a growth rate of $1.81 \mathrm{~m}$ $\mathrm{yr}^{-1}$ for Sonneratia compared to $0.3 \mathrm{~m} \mathrm{yr}^{-1}$ for Ceriops in plantation establishment. Higher salinity fluctuations in the A. marina zone may have needed additional root investment for nutrient uptake in hypersaline circumstances, as seen by the Avicennia zone's high root: shoot ratio. Because most of its roots are above ground in prop roots, $R$. mucronata accumulated less biomass below. The upper layer $(0-20) \mathrm{cm}$ of all mangrove zones has a higher percentage of root growth, demonstrating that most mangroves are shallow-rooted, with biomass accumulation decreasing with depth. Other studies throughout the world have shown similar findings. Castaneda et al. (2011) found that most of the roots $(62-85 \%)$ were distributed in the shallow root zone of the Everglade mangroves in America. In a top/root biomass ratio study in mangroves in Southeast Asia, Komiyama et al. (2000) found that root biomass decreased with depth. According to most research, fine roots, which are essential for aeration and nutrient acquisition, produce the maximum biomass and are located near the surface (Tamooh et al., 2008). Because of the anoxic nature of the mangrove ecosystem, shallow roots improve gaseous exchange at the rooting zone and nutrient uptake from tides and runoff.

Compared to terrestrial forests, mangroves often collect substantial amounts of biomass in their below-ground roots, resulting in a significantly higher root: shoot ratio (Komiyama et al., 2000). In terrestrial forests, belowground biomass accounts for less than $30 \%$ of total biomass, while, in mangroves, root biomass accounts for $40-60 \%$ of total biomass (Saenger 1982; Lugo 1990). On the other hand, R. mucronata, C. tagal, and A. marina zones exhibited lower below-ground biomass accumulation of $15 \%, 23 \%$, and $33 \%$, respectively. The considerable investment in below-ground biomass found in the $S$. alba zone provides stability against strong tidal velocities and increases surface area for gaseous exchange. 
Some species, such as A. marina, tend to make significant investments in root biomass, which may reflect the difficulties of growing in nutrient-depleted, hypoxic, and unstable soils. The current study found a below-ground biomass accumulation rate of 1.3 (range: 1.2-1.4 $\mathrm{t} \mathrm{ha}^{-1} \mathrm{yr}^{-1}$ ) for the $R$. mucronata zone, significantly greater than the 0.2 $\mathrm{t} \mathrm{ha} \mathrm{ha}^{-1} \mathrm{yr}^{-1}$ for Rhizophora apiculata in the Hinchinbrook channel, Australia (Clough, 1998). Similarly, the contribution of below-ground biomass to total biomass accumulation was 14 percent, which was slightly greater than the 8.5 percent recorded for the Rhizophora species in Malaysia (Ong et al. 1995). Gong and Ong (1990) reported a below-ground biomass accumulation rate of 1.2 to $3.6 \mathrm{t}$ $\mathrm{ha}^{-1} \mathrm{yr}^{-1}$ for A. marina, which was similar to the results of this study (range: 1.3-2.5 $\mathrm{t} \mathrm{ha} \mathrm{ha}^{-1} \mathrm{yr}^{-1}$ ). A biomass accumulation of $1.5 \mathrm{t} \mathrm{ha}^{-1} \mathrm{yr}^{-1}$ is estimated in the neotropical mangroves of Florida, United States (McKee and Faulkner, 2000). The estimated lower ground biomass increases of the Rhizophora species in Honduras by Cahoon et al. (2003) are $0.27 \mathrm{tha}^{-1} \mathrm{yr}^{-1}$.

\section{Total biomass and ratio of $A G B: B G B$}

According to the findings of this study, zones on the seaward edge generated total biomass than those on the landward edge (Figure 10). Differences in total biomass accumulation rates could be primarily attributable to salinity differences. Salinity does not vary significantly because the $\mathrm{S}$. alba and $\mathrm{R}$. mucronata zones get daily tidal floods. The A. marina and $C$. tagal zones, on the other hand, only receive tidal inundation at spring tide, exposing the plants to a wider range of salinity fluctuation and, as a result, higher salinity stress that inhibits growth. The existence of spatial changes in environmental conditions across the forest complex is confirmed by a considerable difference in biomass accumulation between the seaward $S$. alba, $R$. mucronata zones, and the landward A. marina and C. tagal zones.

The total biomass accumulation for $R$. mucronata $(8.5$ $0.8 \mathrm{t}$ ha-1) in this study is larger than the $5.1 \mathrm{t}$ ha- $1 \mathrm{yr}-1$ reported for an 80-year-old natural Rhizophora apiculata plantation in Malaysia (Putz and Chan, 1986). Other complicating variables such as forest age, species composition, management regime, and local climatic change may alter biomass allocation patterns, resulting in observed disparities between forests (Kairo et al. 2008; Tamooh et al. 2008). Plantations have been shown to accumulate more biomass than natural forests, which could be due to superior management, such as uniform spacing that reduces competition and better climatic and substrate conditions.

In this study, a high root: shoot ratio of nearly $1: 1$ was confirmed for the $S$. alba zone, with below-ground biomass accounting for $43 \%$ biomass. In contrast, the Rhizophora zone had the lowest R:S ratio of 1:6. A BGB: AGB ratio of 1:4 was found in a 12-year-old replanted $R$. mucronata plantation in Kenya (Kairo et al., 2008). This disparity could have arisen as a result of differences in management. While the current study was conducted in a natural forest, a related prior survey by Kairo et al. (2008) was born in an $R$. mucronata plantation, where management regimes such as spacing and pruning may have influenced tree thriving. This study found a root: shoot biomass accumulation ratio ranging from 1:6 in the Rhizophora zone to $1: 1$ in the Sonneratia zone, with an overall forest ratio of 2:5, which was higher than the R:S ratio of 1:4 found by Ong et al. (1995) in a 20-year Rhizophora species plantation in Malaysia's Matang mangrove forest. It was also higher than the R:S ratio of 1:4 found in terrestrial forests (Cairns et al. 1997). These findings show that mangroves devote more of their biomass to roots to cope with the unstable, soft, anoxic, hypersaline, and nutrient-deficient sediments they grow on and secure the stability and anchorage of the tree (Komiyama et al. 2008).

\section{Leaf phenology}

The considerable variation in leaf phenology among the studied species was a notable finding. $C$. tagal showed a bimodal pattern with peak leaf emergence between April and June and November and December, whereas A. marina had a unimodal pattern with peak leaf production and loss between May and July. R. mucronata had a multimodal pattern, but $S$. alba had a continuous leaf production and losses pattern. Similar findings were made in previous research at Gazi for $R$. mucronata and A. marina (Wang'ondu et al., 2010). Leaf production and losses were unimodal and highly seasonal in A. marina, but leaf gain and loss in $R$. mucronata were constant, with peak production occurring during the wet season. Slim et al. (1996) reported comparable phenological features in $R$. mucronata while working in Gazi, with litterfall peaking during the dry season. Sherman et al. (2010) found that leaf production and losses were continuous in Rhizophora stylosa on Okinawa Island, Japan; however, losses were more evenly distributed.

Mangroves regulate the cellular salt concentration in one way by accumulating salts in their leaves, which are then excreted (Ball and Munns 1992). Evapotranspiration is higher during dry seasons, and species like $R$. mucronata adapt by yellowing and shedding leaves to reduce evapotranspiration. Seasonality in litter production has been seen in other mangrove species as well. Coupland et al. (2005) found that leaf production was linked to leaf fall in Australia. The vegetative and reproductive phenology timing was likely to coincide with specific climatic circumstances, including temperature and rainfall.

\section{Regression equation on biomass accumulation}

The $S$. alba, $R$. mucronata, and $C$. tagal zones showed poor connections in the equations created to represent the interaction between below ground and above ground biomass accumulation. The connection for the Avicennia zone, on the other hand, was stronger, and hence this equation can be utilized to predict below-ground biomass accumulation in the A. marina zone. The short time of data collection or a flaw in the approach employed to estimate belowground biomass accumulation could explain the low belowground biomass for the three species. In a review of the methods used to estimate the below-ground biomass, Vogt et al. (1996), working in the mangrove forest of Puerto Rico, cautioned against using this technique due to 
labor difficulties, while Sánchez (2006) in South Florida mangroves pointed to the potential for using the growth core technique to estimate the below-ground biomass with significant success. Cutting the roots during the creation of the in-growth core, on the other hand, may cause root growth to be delayed, resulting in an underestimate of root output. The findings of this research could have similar consequences.

In conclusion, this study aims to investigate the accumulation of structure, biomass, and environmental factors in the four dominant mangrove areas of Mangrove Forests in Gazi Bay. The following conclusions can be drawn based on the study results: Environmental factors significantly affect the accumulation of biomass in mangrove forests. Salinity was found to play a greater role under the studied environmental variables because more biomass accumulation occurred in wet seasons with a low salinity level.

In the Sonneratia, Rhizophora, and Ceriops species zones, the correlation between above-ground and belowground biomass accumulation was weak, while in the $A$. marina species zone, it was intense. Thus, only belowground biomass accumulation of $A$. marina can be predicted from above-ground biomass accumulation using the equations used in this study.

When comparing the combined below ground: aboveground biomass of mangroves to that of terrestrial vegetation, it is clear that mangroves collect more belowground biomass than terrestrial forests, proving their uniqueness. The current study found that different mangrove species zones have significant differences in above-ground, below-ground, and total biomass accumulation.

\section{REFERENCES}

Amarasinghe MD, Balasubramaniam S. 1992. Net primary productivity of two mangrove forest stands on the northwestern coast of Sri Lanka. Hydrobiologia 247 (1): 37-47. DOI: 10.1007/BF00008203.

Ball MC, Munns R, 1992. Plant responses to salinity under elevated atmospheric concentrations of $\mathrm{CO}_{2}$. Austr J Bot 40 (5): 515-525. DOI: 10.1071/BT9920515.

Bosire JO, Dahdouh-Guebas F, Kairo JG, Koedam N. 2003. Colonization of non-planted mangrove species into restored mangrove stands in Gazi Bay, Kenya. Aquat Bot 76 (4): 267-279. DOI: 10.1016/S03043770(03)00054-8.

Bosire JO, Dahdouh-Guebas F, Walton M, Crona BI, Lewis III RR, Field C, Kairo JG, Koedam N. 2008. Functionality of restored mangroves: a review. Aquat Bot 89 (2): 251-259.

Bouillon S, Borges AV, Castañeda-Moya E, Diele K, Dittmar T, Duke NC, Kristensen E, Lee SY, Marchand C, Middelburg JJ, RiveraMonroy VH, Smith III TJ, Twilley R. 2008. Mangrove production and carbon sink: A revision of global budget estimates. Global Biogeochem Cycl 22 (2): 1-12. DOI: 10.1029/2007GB003052.

Cahoon DR, Hensel P, Rybczyk J, McKee KL, Proffitt CE, Perez BC. 2003. Mass tree mortality leads to mangrove peat collapse at Bay Islands, Honduras after Hurricane Mitch. J Ecol 91 (6): 1093-1105. DOI: 10.1046/j.1365-2745.2003.00841.x.

Cairns MA, Brown S, Helmer EH, Baumgardner GA. 1997. Root biomass allocation in the world's upland forests. Oecologia 111 (1): 1-11. DOI: $10.1007 / \mathrm{s} 004420050201$.

Christensen B. 1978. Biomass and primary production of Rhizophora apiculata Bl. in a mangrove in southern Thailand. Aquat Bot 4: 4352. DOI: $10.1016 / 0304-3770(78) 90005-0$.
Clarke PJ, Kerrigan RA. 2002. The effects of seed predators on the recruitment of mangroves. J Ecol 90 (4): 728-736. DOI: 10.1046/j.1365-2745.2002.00705.x.

Clough B. 1998. Mangrove forest productivity and biomass accumulation in Hinchinbrook Channel, Australia. Mangroves Salt Marshes 2 (4): 191-198. DOI: 10.1023/A:1009979610871.

Costanza R, d'Arge R, de Groot R, Farber S, Grasso M, Hannon B, Limburg K, Naeem S, O'Neill RV, Paruelo J, Raskin RG, Sutton P, van den Belt M. 1997. The value of the world's ecosystem services and natural capital. Nature 387 (6630): 253-260. DOI: $10.1038 / 387253 \mathrm{a} 0$.

Coupland GT, Paling EI, McGuinness KA. 2005. Vegetative and reproductive phenologies of four mangrove species from northern Australia. Austr J Bot 53 (2): 109-117. DOI: 10.1071/BT04066.

Day JW, Coronado-molina C, Vera-Herrera FR, Twilley R, RiveraMonroy VH, Alvarez-Guillen H, Day R, Conner W. 1996. A 7-year record of above-ground net primary production in a southeastern Mexican mangrove forest. Aquat Bot 55 (1): 39-60. DOI: 10.1016/0304-3770(96)01063-7.

Donato DC, Kauffman JB, Murdiyarso D, Kurnianto S, Stidham M, Kanninen M. 2011. Mangroves among the most carbon-rich forests in the tropics. Nat Geosci 4 (5): 293-297. DOI: 10.1038/ngeo1123.

FAO. 1994. Mangrove Forest Management Guidelines. FAO Forestry Paper 117, FAO, Rome.

FAO. 2007a. State of the world's forests. Food and Agriculture Organization of the United Nations, Rome.

FAO. 2007b. The World's Mangroves 1980-2005. Forestry Paper 153, FAO, Rome.

Giri C, Ochie'ng E, Tieszen LL, Zhu Z, Singh A, Loveland T, Masek J, Duke N. 2011. Status and distribution of mangrove forests of the world using earth observation satellite data. Global Ecol Biogeogr 20 (1): 154-159. DOI: 10.1111/j.1466-8238.2010.00584.x

Holdridge LR, Grenke WC, Hatheway WH, Liang T, Tosi JA. 1971. Forest Environment in Tropical Life Zones. Pergamon Press, NY.

Kairo JG, Bosire J, Langat J, Kirui B, Koedam N. 2009. Allometry and biomass distribution in replanted mangrove plantations at Gazi Bay, Kenya. Aquat Conserv Mar Freshw Ecosyst 19 (S2): S63-S69. DOI: 10.1002/aqc.1046.

Kairo JG, Dahdouh-Guebas F, Bosire J, Koedam N. 2001. Restoration and management of mangrove systems-a lesson for and from the East African region. South Afr J Bot 67 (3): 383-389. DOI: 10.1016/S0254-6299(15)31153-4.

Kairo JG, Dahdouh-Guebas F, Gwada PO, Ochieng C, Koedam N. 2002a. Regeneration status of mangrove forests in Mida Creek, Kenya: A compromised or secured future? Ambio 31: 562-568. DOI: 10.1579/0044-7447-31.7.562.

Kairo JG, Kivyatu B, Koedam N. 2002b. Application of remote sensing and GIS in the management of mangrove forests within and adjacent to Kiunga Marine Protected Area, Lamu, Kenya. Environ Dev Sustain 4 (2): 153-166. DOI: 10.1023/A:1020890711588.

Kairo JG, Lang'at JKS, Dahdouh-Guebas F, Bosire JO, Karachi M. 2008. Structural development and productivity of replanted mangrove plantations in Kenya. For Ecol Manag 255 (7): 2670-2677. DOI: 10.1016/j.foreco.2008.01.031.

Kirui B, Kairo JG, Karachi M. 2006. Allometric equations for estimating above ground biomass of Rhizophora mucronata Lamk. (Rhizophoraceae) mangroves at Gazi Bay, Kenya. Western Indian Ocean J Mar Sci 5 (1): 27-34. DOI: 10.4314/wiojms.v5i1.28496

Komiyama A, Havanond S, Srisawatt W, Mochida Y, Fujimoto K, Ohnishi T, Ishihara S, Miyagi T. 2000. Top/root biomass ratio of a secondary mangrove (Ceriops tagal (Perr.) C. B. Rob.) forest. For Ecol Manag 139: 127-134. DOI: 10.1016/S0378-1127(99)00339-4.

Komiyama A, Jintana V, Sangtiean T, Kato S. 2002. A common allometric equation for predicting stem weight of mangroves growing in secondary forests. Ecol Res 17: 415-418. DOI: 10.1046/j.14401703.2002.00500.x.

Komiyama, Ong JE, Poungparn S, 2008. Allometry, biomass, and productivity of mangrove forests: A review. Aquat Bot 89 (2): 128137. DOI: 10.1016/j.aquabot.2007.12.006.

Lugo AE. 1990. Fringe wetlands. In: Lugo AE, Brinson MM, Brown S (eds). Ecosystems of the World. Elsevier, Amsterdam.

Macnae W. 1968. A general account of the flora and fauna of mangrove swamps and forests in the Indo-West-Pacific region. In: Russel FS, Yonge M (eds) Adv Mar Biol 6: 74-165. DOI: 10.1016/S00652881(08)60438-1. 
Matthijs S, Tack J, van Speybroeck D, Koedam N. 1999. Mangrove species zonation and soil redox state, sulphide concentration, and salinity in Gazi Bay (Kenya), a preliminary study. Mangroves Salt Marshes 3 (4): 243-249. DOI: 10.1023/A:1009971023277.

McKee KL, Faulkner PL. 2000. Restoration of biogeochemical function in mangrove forests. Restor Ecol 8 (3): 247-259. DOI: 10.1046/j.1526100x.2000.80036.x.

Mohamed M, Neukermans G, Kairo J, Dahdouh-Guebas F, Koedam N 2009. Mangrove forests in a peri-urban setting: the case of Mombasa (Kenya). Wetlands Ecol Manag 17 (3): 243-255. DOI: 10.1007/s11273-008-9104-8.

Mumby PJ, Broad K, Brumbaugh DR, Dahlgren CP, Harborne AR, Hastings A, Holmes KE, Kappel CV, Micheli F, Sanchirico JN. 2008. Coral reef habitats as surrogates of species, ecological functions, and ecosystem services. Conserv Biol 22 (4): 941-951. DOI: 10.1111/j.1523-1739.2008.00933.x.

Ong JE, Gong WK, Clough BF. 1995. Structure and productivity of a 20year-old stand of Rhizophora apiculata Bl. mangrove forest. J Biogeogr 22: 417-424. DOI: 10.2307/2845938.

Saenger P. 1982. Morphological, anatomical, and reproductive adaptations of Australian mangroves. In: Clough BF (eds) Mangrove Ecosystems in Australia. Australian National University Press, Canberra.

Saenger P. 2002. Mangrove Ecology, Silviculture, and Conservation. Kluwer Academic Publishers, Dordecht, The Netherlands. DOI: 10.1007/978-94-015-9962-7.

Schmitz N. Jansen S. Verheyden A. Kairo JG, Beeckman H, Koedam N. 2007. Comparative anatomy of inner vessel pits in two mangrove species growing along a natural salinity gradient in Gazi Bay, Kenya. Ann Bot 100 (2): 271-281. DOI: 10.1093/aob/mcm103.

Sherman RE, Fahey TJ, Battles JJ. 2000. Small-scale disturbance and regeneration dynamics in a neotropical mangrove forest. J Ecol 88 (1): 165-178. DOI: 10.1046/j.1365-2745.2000.00439.x.

Slim FJ, Gwada PM, Kodjo M, Hemminga MA. 1996. Biomass and litterfall of Ceriops tagal and Rhizophora mucronata in the mangrove forest of Gazi Bay, Kenya. Mar Freshw Res 47 (8): 999-1007. DOI: 10.1071/MF9960999.

Sukardjo S. 1987. Natural regeneration status of commercial mangrove species (Rhizophora apiculata and Bruguiera gymnorrhiza) in the mangrove forest of Tanjung Bungin, Banyuasin District, South Sumatra. For Ecol Manag 20 (3-4): 233-252. DOI: 10.1016/03781127(87)90082-X.

Tamooh F, Huxham M, Karachi M, Mencuccini M, Kairo JG, Kirui B. 2008. Below-ground root yield and distribution in natural and replanted mangrove forests at Gazi bay, Kenya. For Ecol Manag 256 (6): 1290-1297. DOI: 10.1016/j.foreco.2008.06.026

Vogt KA, Vogt DJ, Bloomfield J. 1998. Analysis of some direct and indirect methods for estimating root biomass and production of forests at an ecosystem level. Plant Soil 200: 71-89. DOI: 10.1023/A:1004313515294.

Wang'ondu VW, Kairo JG, Kinyamario J, Mwaura FB, Bosire J, Dahdouh Guebas F, Koedam N. 2010. Phenology of Avicennia marina (Forsk) Vierh. in a disjunctly zoned mangrove stand in Kenya Western Indian Ocean. J Mar Sci 9 (2): 135-144.

Watson JG. 1928. Mangrove forests of the Malay Peninsula. Fraser and Neave, Singapore. 